\title{
A atuação profissional do Geógrafo na elaboração dos Estudos e Relatórios de Impacto Ambiental (EIAs/RIMAs)
}

\section{The professional performance of the Geographer in the elaboration of Environmental Impact Studies and Reports (EIAs / RIMAs)}

\author{
Henrique Elias Pessoa Gutierres \\ Geógrafo do Departamento de Geociências (Laboratório de Planejamento e Gestão \\ Ambiental/LAPLAG) - UFPB \\ Doutorando do Programa de Pós-Graduação em Geografia - UFPE, Brasil \\ hepg86@hotmail.com \\ Camilla Jerssica da Silva Santos \\ Graduada em Geografia - UFPB \\ Mestranda do Programa de Pós-Graduação em Geografia - UFPB, Brasil \\ camilla.jerssica@hotmail.com \\ Valdeniza Delmondes Pereira \\ Técnica em Meio Ambiente - IFPB e Graduada em Geografia - UFPB, Brasil \\ del_mondes@hotmail.com \\ Jéssika de Oliveira Neles Rodrigues \\ Graduada em Engenharia Ambiental - UFPB \\ Mestranda do Programa de Pós-Graduação em Desenvolvimento e Meio \\ Ambiente - UFPB, Brasil \\ jessikaonr@hotmail.com
}

\begin{abstract}
Resumo
A elaboração dos Estudos de Impacto Ambiental é uma das áreas que vem demandando a atuação do geógrafo. Diante da complexidade de tal estudo, o mesmo exige uma equipe multidisciplinar de profissionais para a sua elaboração. Dessa forma, este artigo se propõe a apresentar dados reais sobre a atuação dos geógrafos na elaboração dos EIAs/RIMAs protocolados no órgão ambiental do estado da Paraíba, entre os anos de 2000 e 2015. Tem como base uma pesquisa aplicada e descritiva através do método documental. Os resultados demonstraram que o geógrafo foi um dos profissionais mais presentes nas equipes dos EIAs analisados e que existe a necessidade em se discutir as possibilidades de atuação profissional em relação às diversas áreas da geografia, tendo a análise integrada como uma virtude do geógrafo, contribuindo para o licenciamento ambiental de empreendimento, obra ou atividade potencialmente causadoras de significativa do meio ambiente.
\end{abstract}

Palavras-chave: Geógrafos; EIAs/RIMAs; Licenciamento Ambiental.

\begin{abstract}
The elaboration of Environmental Impact Studies is one of the areas that has been demanding the geographer's performance. Given the complexity of such a study, it requires a multidisciplinary team of professionals for its elaboration. Thus, this article proposes to present real data on the role of geographers in the elaboration of EIAs / RIMAs filed with the environmental agency of the state of Paraíba between 2000 and 2015. It is based on applied and descriptive research through the method documentary. The results showed that the geographer was one of the most present
\end{abstract}


professionals in the analyzed EIA teams and that there is a need to discuss the possibilities of professional performance in relation to the various areas of geography, having integrated analysis as a virtue of the geographer, contributing to environmental licensing of a project, work or activity potentially causing significant degradation of the environment.

Keywords: Geographers; EIAs / RIMAs; Environmental Licensing.

\section{INTRODUÇÃO}

O planejamento, a implantação/construção e a operação de obras e atividades, tanto por parte do poder público, como por parte da iniciativa privada, são uma realidade em qualquer lugar do mundo. Por isso, como toda ação humana, a mesma deve ser analisada e compreendida pelo viés natural, econômico, social e cultural. Para isso, o poder público e a coletividade fazem uso de instrumentos de planejamento e de gestão ambiental, que visam evitar, minimizar e/ou compensar os impactos ambientais negativos e potencializar os positivos, decorrentes da construção ou operação de algum empreendimento ou atividade. Dentre esses instrumentos, o licenciamento ambiental destaca-se como obrigatório para a implantação e a operação das mais diversas atividades econômicas. Contudo, sabe-se que tal instrumento possui níveis de exigências diferenciados de acordo com o tipo do empreendimento a ser licenciado e a sua localização geográfica. Dessa maneira, para analisar a viabilidade ambiental de empreendimentos/atividades com significativo poder de degradação ambiental, a legislação ambiental brasileira impõe a elaboração e a apresentação do Estudo de Impacto Ambiental (EIA) e o seu respectivo Relatório de Impacto Ambiental (RIMA), como um estudo ambiental que visa subsidiar o licenciamento ambiental de empreendimentos de maior complexidade.

O EIA contempla conhecimentos das mais diversas áreas (meio físico - geologia, geomorfologia, climatologia, pedologia, recursos hídricos etc.; meio biológico - fauna e flora; socioeconômico - dinâmica populacional, condições de vida da população - saúde, educação, habitação etc., atividades econômicas, infraestrutura e serviços públicos, sistema viário, patrimônio histórico e cultural etc.). Logo, ao se tratar de um estudo que contempla tantos conhecimentos, impossível que a sua elaboração fique sob a responsabilidade de um único profissional ou de uma única profissão, exigindo a presença de uma equipe multidisciplinar. $\mathrm{O}$ aperfeiçoamento das profissões exige que a sociedade se conscientize do papel e da importância do exercício profissional para o desenvolvimento social e econômico do país. Gutierres et al. (2018) apresentaram um ranking dos profissionais mais requisitados pelas equipes elaboradoras dos EIAs/RIMAs protocolados no órgão estadual de meio ambiente da Paraíba, entre os anos de 2000 e 2015 . No entanto, os autores destacam que é mais comum encontrar publicações científicas que têm se debruçado sobre a qualidade dos EIAs e a consequente eficácia dos mesmos. Sendo assim, poucos 
são os trabalhos que enfatizam a preocupação com a atuação profissional e a composição da equipe técnica responsável pela elaboração dos estudos ambientais (GLASSON; SALVADOR, 2000; KIRCHHOFF, 2006; MORGAN et al., 2012; GUTIERRES et al., 2018).

Dentre os diversos profissionais (biólogos, geólogos, engenheiros ambientais, geógrafos, engenheiros florestais, advogados, engenheiros civis, sociólogos, economistas etc.) que comumente estão presentes nessas equipes, este artigo se propõe a apresentar dados e discutir a atuação do geógrafo, cuja profissão encontra-se regulamentada pela Lei Federal $n^{\circ}$ 6.664, de 26 de junho de 1979, e fiscalizado pelo Conselho Regional de Engenharia e Agronomia (CREA). As oportunidades de trabalho para o geógrafo podem acontecer tanto no serviço público, como na iniciativa privada na condição de empregado de alguma empresa (indústria, consultoria ambiental, por exemplo), empreendedor (proprietário de empresas de consultoria ambiental, planejamento urbano ou geotecnologias, por exemplo), profissional autônomo etc. Para Signori e Verdum (2009, p.146), as "áreas de meio ambiente, planejamento, gestão territorial, gestão urbana e agrária" são as "áreas de atuação por excelência do geógrafo".

No tocante a existência de artigos em periódicos científicos brasileiros sobre o geógrafo, nota-se uma baixa quantidade de estudos que tenham como foco investigar e conhecer melhor o seu mercado de trabalho. Apesar disso, é possível encontrar alguns artigos que abordam a formação e o mercado de trabalho do geógrafo (SILVA, 1983; ANDRADE, 1986/1987; MARANGON, 1987; ROSA, 1988; SUERTEGARAY; SCHAFFER, 1988; SEEMANN, 2000/2001; VERDUM, 2005; SIGNORI; VERDUM, 2009; GUTIERRES et al., 2018; SANCHES; VILLALOBOS, 2018) e publicações de outra natureza - livros, capítulos de livro, manual técnico e dissertações (VELOSO, 1996; CREA-CE, 2002; AB'SABER, 2007; PAES, 2010; PAES E VENTURI, 2011; APROGEOCE, 2015). Como exemplo da atuação profissional do geógrafo na elaboração dos EIAs/RIMAs, recentemente, Sanches e Villalobos (2018) estudaram e analisaram o EIA de um condomínio residencial, localizado no noroeste do Paraná, propondo a análise do meio físico por meio das competências do geógrafo presentes na Lei Federal $n^{\circ} 6.664 / 79$.

Logo, tomando os questionamentos de Andrade (1987), sobre quais as perspectivas do geógrafo, como profissional, no Brasil, sendo necessárias duas questões fundamentais: qual a formação profissional do geógrafo? E qual mercado de trabalho que oferece oportunidades ao profissional de Geografia? Tomando esse segundo questionamento, é que este artigo se propõe a apresentar dados reais sobre a atuação dos geógrafos na elaboração dos EIAs/RIMAs protocolados no órgão ambiental do estado da Paraíba, entre os anos de 2000 e 2015, discutindo tal atuação frente a diversos parâmetros (temporalidade, ramos de atividades, profissionais de outras áreas, áreas de atuação no EIA etc.). 


\subsection{A Profissão de Geógrafo}

No Brasil, o título profissional de geógrafo é concedido a toda pessoa portadora do diploma de bacharelado em Geografia e que esteja registrada no Conselho Regional de Engenharia e Agronomia (CREA), conforme determina a Lei Federal $n^{\circ}$ 6.664/79 (disciplina a profissão de Geógrafo) (BRASIL, 1979). Anteriormente à citada lei, Marangon (1987) destaca a década de 1930 como tendo sido muito significativa para a geografia brasileira, a exemplo da criação dos primeiros cursos universitários de geografia, a criação da Associação dos Geógrafos Brasileiros (AGB) e a criação do Conselho Nacional de Geografia (1937). Com relação à lei do geógrafo de 1979, a autora destaca que a apresentação do Projeto de Lei aconteceu no ano de 1968. E, quase oito anos após a sua promulgação, alguns problemas relacionados ao desempenho das atividades do geógrafo eram constatados: mercado de trabalho, formação profissional, condições salariais e a necessidade da criação e/ou fortalecimento das entidades associativas de geógrafos (MARANGON, 1987). Tais entidades vieram a ser criadas após a aprovação da lei, intituladas como Associação Profissional dos Geógrafos (APROGEO), exceto a AGP/RS (Associação dos Geógrafos Profissionais do Rio Grande do Sul), criada antes, em 1969, sendo a primeira associação dessa natureza (voltada para a defesa dos geógrafos), porém adotando outra sigla. Posteriormente, estados como o Ceará, Paraíba, São Paulo, Minas Gerais, Alagoas, Paraná, Distrito Federal, Santa Catarina, Maranhão, Bahia, Rio Grande do Norte, Acre, Rondônia etc., vieram a criar as suas APROGEOs (Associação Profissional dos Geógrafos).

Pensar na atuação de qualquer profissão requer analisar a sua formação acadêmica e a legislação profissional. Entende-se que no momento da graduação, o futuro geógrafo precisa se preocupar em gerar competências resultantes dos componentes cursados, de forma a permitir a execução dos mais diversos serviços. Para isso, os cursos de graduação necessitam dispor de uma boa infraestrutura (salas de aula, bibliotecas atualizadas, laboratórios de diversas áreas geoprocessamento, planejamento urbano, geografia agrária, geografia econômica, geomorfologia, pedologia, climatologia, biogeografia, planejamento e gestão ambiental etc.), como também a inclusão do estágio curricular obrigatório, por meio de convênios com empresas privadas e órgãos públicos; além de uma carga horária total do curso e dos componentes curriculares, que permitam um maior aprofundamento possível dos conhecimentos e das habilidades.

O geógrafo está inserido no grupo dos "Profissionais em pesquisa e análise geográfica", segundo a classificação do extinto Ministério do Trabalho e Emprego, sob o número 2513-05. Na descrição sumária consta que são profissionais que (BRASIL, 2013): 
Estudam a organização espacial por meio da interpretação e da interação dos aspectos físicos e humanos; regionalizam o território em escalas que variam do local ao global; avaliam os processos de produção do espaço, subsidiando o ordenamento territorial; participam do planejamento regional, urbano, rural, ambiental e da formulação de políticas de gestão do território; procedem estudos necessários ao estabelecimento de bases territoriais; emitem laudos e pareceres técnicos; monitoram uso e ocupação da terra, vistoriam áreas em estudo, estudam a pressão antrópica e diagnosticam impactos e tendências (Classificação Brasileira de Ocupação - CBO; Ministério do Trabalho e Emprego).

Diante da descrição das áreas de atuação descritas pela $\mathrm{CBO}$, compreende-se que o geógrafo é um profissional que pode atuar em órgãos públicos de diversas áreas (meio ambiente, assistência e extensão rural, demarcação de terras, turismo, planejamento urbano, socioeconomia, cartografia, geotecnologias, climatologia, gestão de recursos hídricos, etc.), empresas privadas indústrias (setores de meio ambiente, geotecnologias, responsabilidade social etc.), escritórios de consultoria (exemplos: planejamento e gestão ambiental, socioeconomia, geoprocessamento), ONGs (Organizações Não Governamentais) e como profissional liberal.

Sampaio et al. (2017) analisaram as áreas de atribuições do Geógrafo, de acordo com a Lei Federal $\mathrm{n}^{\mathrm{o}} 6.664 / 79$ e as habilidades e competências do profissional segundo as Diretrizes Curriculares Nacionais (DCN's), de acordo com o Parecer CNE/CES 492 de 2001 (BRASIL, 2001). Segundo os autores, “as DCN's mantêm as atribuições previstas pela Lei, mas detalham e introduzem novas competências profissionais, ampliando o leque de atividades profissionais [...]" (2017, p.277). Eles consideraram quatro grupos para as atribuições legais estabelecidas pela lei do geógrafo (Planejamento Territorial; Estudos e Análise Ambiental; Pesquisa de Mercado; Mapeamento/Geotecnologias), enquanto que as competências relativas aos bacharelados, baseadas nas DCN's, foram consideradas da seguinte forma: "Planejamento Territorial"; "Estudos e análise ambiental"; "Pesquisa/Ensino"; "Mapeamento/Geotecnologias"; e "Turismo". O grupo de "estudos e análise ambiental", que contempla a elaboração dos Estudos de Impacto Ambiental, apresentou $36 \%$ de participação no total de atribuições estabelecidas pela lei do Geógrafo, enquanto que nas competências das DCNs totalizou 32\%. No primeiro cenário foi superada, apenas, pelo "Planejamento Territorial" (50\%), enquanto que no segundo cenário respondeu como a área de maior quantidade de competências relativas ao bacharelado. Portanto, demonstrando que a área ambiental é um potencial nicho de mercado para os geógrafos, com destaque para o licenciamento ambiental e a elaboração dos estudos ambientais, a exemplo do EIA/RIMA. 


\title{
1.2 Licenciamento Ambiental e o Estudo de Impacto Ambiental
}

O licenciamento ambiental constitui um dos instrumentos elencados no artigo $9^{\circ}$ da Lei da Política Nacional do Meio Ambiente (Lei Federal $n^{\circ}$ 6.938/81) e os seus objetivos explicitados no artigo 10 da mesma lei:

\begin{abstract}
Art.10 - A construção, instalação, ampliação e funcionamento de estabelecimentos e atividades utilizadoras de recursos ambientais, considerados efetiva ou potencialmente poluidores, bem como os capazes, sob qualquer forma, de causar degradação ambiental, dependerão de prévio licenciamento por órgão estadual competente, integrante do SISNAMA, sem prejuízo de outras licenças exigíveis.
\end{abstract}

Nas últimas décadas, o conceito de licenciamento ambiental vem sendo apresentado por meio de leis e resoluções, bem como na literatura técnica e científica. A Lei Complementar $n^{\circ}$ 140/2011, em seu inciso I do art. $2^{\circ}$, define como "o procedimento administrativo destinado a licenciar atividades ou empreendimentos utilizadores de recursos ambientais, efetiva ou potencialmente poluidores ou capazes, sob qualquer forma, de causar degradação ambiental" (BRASIL, 2011). Conforme previsto na Resolução CONAMA n 237/97, os "estudos ambientais" são "todos e quaisquer estudos relativos aos aspectos ambientais relacionados à localização, instalação, operação e ampliação de uma atividade ou empreendimento, apresentado como subsídio para a análise da licença requerida [...]”. O EIA/RIMA encontra-se inserido nessa definição, além de outros estudos ambientais, já que nem todo licenciamento ambiental necessita de EIA/RIMA, como explicam Pereira e Gutierres (2018, p.180):

[...] a legislação impõe a obrigação de que o licenciamento ambiental seja acompanhado do Estudo de Impacto Ambiental (EIA), que é um dos estudos ambientais possíveis de serem solicitados pelos órgãos ambientais (federal, estaduais ou municipais). Contudo, nem todos os empreendimentos/atividades são capazes de causar impactos ambientais significativos, e, portanto, a legislação possibilita a exigência de estudos ambientais simplificados (Relatório Ambiental Simplificado - RAS; Estudo de Viabilidade Ambiental - EVA), que não possuem a profundidade e a complexidade do EIA/RIMA.

Sendo assim, o EIA será solicitado para os empreendimentos e atividades com significativo poder de degradação ambiental. Vale destacar que o art. 225 da Constituição Federal impõe ao poder público (juntamente com a coletividade) a obrigação de atuar na defesa e na preservação do meio ambiente, tendo em vista o direito das gerações presentes e futuras. Para tanto, o inciso IV do artigo 225, destaca que uma das incumbências atribuídas ao poder público é: "IV exigir, na forma da lei, para instalação de obra ou atividade potencialmente causadora de significativa degradação do meio ambiente, estudo prévio de impacto ambiental, a que se dará publicidade”. Portanto, tal estudo ambiental subsidiará a análise da licença ambiental requerida. 
Por se tratar de um procedimento administrativo, o licenciamento ambiental se divide em três etapas básicas, de acordo com o tipo da licença ambiental, emitidas de acordo com a fase em que se encontra o empreendimento ou atividade: Licença Prévia - LP; Licença de Instalação - LI; Licença de Operação - LO. Sendo assim, o licenciamento ambiental tem o objetivo de controle prévio (análise da viabilidade locacional e legal), porém, devendo exercer um acompanhamento contínuo da fase de instalação e de operação do empreendimento. Dessa forma, antes da emissão da Licença Prévia, o EIA precisa contemplar o levantamento da literatura técnica, científica e legal, além da realização de trabalhos de campo, de mapeamento e análises de laboratório. Dessa forma, constitui-se num documento detalhado e complexo, que faz uso de uma linguagem técnicocientífica que, em muitos casos, é inacessível ao público leigo. A Resolução CONAMA nº 01/86 definiu uma série de diretrizes para normatizar a elaboração, análise e discussão pública do EIA no Brasil. No tocante à atuação profissional, Nehrer (2002, p.73) destaca que com a publicação dessa resolução:

[...] houve um boom de empresas de consultoria ambiental. Nesta ocasião, as grandes empresas de engenharia organizaram departamentos de meio ambiente instalando equipes multidisciplinares. Após o efeito da bolha de crescimento econômico, a tendência foi o esvaziamento dessas grandes empresas e uma "terceirização" dos serviços de consultoria. Deste modo, permitiu-se o surgimento de empresas médias e menores ocupando espaço no mercado de consultoria ambiental.

Ora, como já salientado, é um instrumento de planejamento, mas também que visa implementar ações nas diversas fases do empreendimento (construção/instalação, operação e desativação - em alguns casos), logo, também um instrumento de gestão ambiental. Para Christofoletti (1999, p. 141):

Os estudos de impactos ambientais constituem instrumentos que integram o conhecimento adquirido na análise dos sistemas ambientais com os objetivos das políticas de planejamento e manejo dos recursos, procurando coordenar a implantação da alternativa de melhor uso por meio de uma avaliação antecipativa. Essa abordagem sempre corresponde à categoria de análise dos impactos antropogênicos. O conhecimento adequado dos sistemas ambientais possibilita compreender suas reações perante os impactos causados pelos projetos sócio-econômicos e avaliar os benefícios e os malefícios a curto, médio e a longo prazo. Baseiam-se no conhecimento das condições reais e na elaboração de cenários futuros como respostas dinâmicas evolutivas.

$\mathrm{O}$ art. $6^{\circ}$, da Resolução CONAMA $\mathrm{n}^{\circ}$ 01/86, elencou algumas atividades técnicas, que devem ser observadas, como uma estrutura mínima a ser obedecida na elaboração do EIA:

Artigo $6^{\circ}-\mathrm{O}$ estudo de impacto ambiental desenvolverá, no mínimo, as seguintes atividades técnicas: 
I - Diagnóstico ambiental da área de influência do projeto, completa descrição e análise dos recursos ambientais e suas interações, tal como existem, de modo a caracterizar a situação ambiental da área, antes da implantação do projeto, considerando:

a) o meio físico - o subsolo, as águas, o ar e o clima, destacando os recursos minerais, a topografia, os tipos e aptidões do solo, os corpos d'água, o regime hidrológico, as correntes marinhas, as correntes atmosféricas;

b) o meio biológico e os ecossistemas naturais - a fauna e a flora, destacando as espécies indicadoras da qualidade ambiental, de valor científico e econômico, raras e ameaçadas de extinção e as áreas de preservação permanente;

c) o meio sócio-econômico - o uso e ocupação do solo, os usos da água e a sócio-economia, destacando os sítios e monumentos arqueológicos, históricos e culturais da comunidade, as relações de dependência entre a sociedade local, os recursos ambientais e a potencial utilização futura desses recursos.

II - Análise dos impactos ambientais do projeto e de suas alternativas, através de identificação, previsão da magnitude e interpretação da importância dos prováveis impactos relevantes, discriminando: os impactos positivos e negativos (benéficos e adversos), diretos e indiretos, imediatos e a médio e longo prazos, temporários e permanentes; seu grau de reversibilidade; suas propriedades cumulativas e sinérgicas; a distribuição dos ônus e benefícios sociais.

III - Definição das medidas mitigadoras dos impactos negativos [...]

IV - Elaboração do programa de acompanhamento e monitoramento [...].

Pelo texto da resolução fica evidente a variedade de conhecimentos solicitados, tornando o EIA um estudo técnico-científico complexo, o que se exige a formação de uma equipe profissional multidisciplinar. Além disso, o MPF (2004, p.22) explica que "para o atendimento às diretrizes mínimas do Estudo, não basta um trabalho apresentado sob a forma de diagnósticos, análises e propostas de programas para três "compartimentos" ou "meios". É importante uma abordagem interdisciplinar do diagnóstico".

Além das diretrizes estabelecidas pela Resolução CONAMA nº 01/86, também deverá ser elaborado um Termo de Referência (TR), um documento que estabelece "um roteiro com a delimitação dos recortes temáticos a serem contemplados nos estudos e avaliações de impactos de um projeto em particular" (MPF, 2004, p.11), a ser firmado junto ao órgão ambiental licenciador e que norteará a elaboração do EIA, tomando as particularidades do empreendimento e as características da área de estudo, norteando, consequentemente, a escolha dos profissionais e as suas respectivas áreas de atuação, que irão compor a equipe técnica elaborada do estudo.

Dessa maneira, a comunidade acadêmica necessita cada vez mais identificar as profissões dos membros das equipes elaboradoras dos EIAs protocolados nos órgãos ambientais (federal, estaduais e municipais) e analisar, criticamente, a atuação dos mesmos. Em pesquisa realizada por Gutierres et al. (2018), tendo analisado quarenta e três EIAs, identificaram os seguintes profissionais como os que mais integraram as equipes (em ordem decrescente): biólogos, geólogos, geógrafos, engenheiros civis, engenheiros florestais, advogados, engenheiros de minas, engenheiros agrônomos, engenheiros ambientais e economistas. Paes (2010), que analisou vinte EIAs protocolados no órgão ambiental do estado de São Paulo, entre os anos de 2000 e 2009, mostrou que os biólogos, geólogos, engenheiros civis e geógrafos, em ordem decrescente, foram os 
profissionais que mais integraram as equipes elaboradoras dos estudos. Portanto, demonstrando certa semelhança dos profissionais mais contratados nas duas pesquisas citadas.

\subsection{Os geógrafos e a elaboração do Estudo de Impacto Ambiental}

Atendendo ao objetivo deste texto, que é focado na elaboração dos EIAs, vale destacar que, normalmente, a elaboração desses estudos fica a cargo de empresas de consultoria ambiental, que se constituem num importante nicho de mercado para os geógrafos. Marangon (1987, p.140), há mais de 30 anos, discorria a respeito de perspectivas favoráveis do mercado de trabalho para o geógrafo, dando o exemplo da "recente exigência de estudos de impacto ambiental para a construção de grandes represas, sem os quais não devem ser liberados recursos federais, levou a uma relativamente grande procura de profissionais ligados aos estudos da natureza, entre os quais se incluem os geógrafos". Portanto, pensar em continuar atuar e ampliar essa atuação requer dos cursos que formam os bacharéis em geografia e dos profissionais geógrafos, a busca por identificar as possibilidades de atuação, melhorando a formação do futuro profissional e aprimorando e consolidando a legislação profissional. Algumas publicações, a exemplo de Paes (2010) e Gutierres et al. (2018), têm demonstrado que a elaboração dos Estudos de Impacto Ambiental (EIAs) continuam sendo um importante campo de atuação para o geógrafo. Silva (2002, p.290) enfatiza a importância da equipe multidisciplinar e cita o geógrafo como um possível profissional habilitado para executar tal serviço:

A qualificação técnica dos membros da equipe depende muito da natureza do empreendimento, mas, por certo, hão de ter habilitação relacionada com os fatores e recursos ambientais - biólogos, botânicos, engenheiros, arquitetos, arqueólogos, químicos, economistas, sociólogos, geógrafos, advogados especialistas em meio ambiente. Nem todos são necessários em todos os projetos, mas alguns talvez sejam indispensáveis sempre.

Se for enfatizada a atuação na elaboração dos estudos do meio físico do EIA, Bitar et al. (2018, p.218) afirmam que para o estudo do "meio físico deve contar especialmente com geólogos, geógrafos, geomorfólogos, pedólogos, hidrólogos, engenheiros geotécnicos, agrônomos, meteorologistas, climatologistas, oceanógrafos, entre outras especialidades correlatas e afeitas a cada caso".

Em se tratando da formação acadêmica durante os cursos de graduação de Geografia, em alguns casos, não são abordados os aspectos referentes à atividade da elaboração do EIA/RIMA e dos procedimentos do licenciamento ambiental, o que gera um certo distanciamento dos futuros profissionais. No entanto, Paes e Venturi (2011, p. 499-500) abordam as qualidades profissionais dos geógrafos e enfatizam que: 
A atuação dos geógrafos na área ambiental é amparada principalmente por seu preparo teórico-metodológico, técnico-científico e por sua postura crítica e ética, atributos que são valorizados na maioria dos cursos de Geografia, além de sua capacidade coordenativa obtida com uma formação multidisciplinar própria do seu bacharelado.

Sem dúvida, a formação multidisciplinar precisa ser sempre valorizada nos Estudos de Impacto Ambiental, o que acaba sendo benéfico para os geógrafos, devido a sua grade curricular multidisciplinar, articulando conhecimentos do meio natural e humano. Como se verá adiante, tanto as disciplinas da vertente da Geografia Humana, como da Geografia Física, permeadas pelas técnicas de cartografia e as geotecnologias, são importantes para o geógrafo quando se trata de elaborar o Estudo de Impacto Ambiental, visto que este profissional, dependendo do nível de especialidade, poderá atuar tanto na elaboração dos estudos do meio físico como também do meio socioeconômico (ou antrópico) e, com menos frequência, no meio biótico. Logo, a sua formação em nível de graduação "possibilita ao geógrafo adquirir habilidade especial para a análise integrada, que acabará sendo sua mais forte estratégia metodológica” (PAES; VENTURI, 2011, p.501). Diante destas particularidades da análise integrada (geográfica), os autores defendem que o geógrafo pode assumir diversas funções na equipe do EIA, a exemplo da coordenação geral do estudo, "por ser essa uma tarefa que exige conhecimento bastante amplo e articulado; que envolve as dimensões física (abiótica), biótica e antrópica (social, num sentido mais amplo); que deve apreender os impactos de forma integrada e não fragmentada [...]" (PAES; VENTURI, 2011, p.501). Tal pensamento é reforçado por Veloso (1996, p.48), que destaca o embasamento teórico-metodológico e técnico:

Em sua formação básica (graduação) o geógrafo adquire conhecimento sobre os diversos componentes dos meios físico, biótico e antrópico, bem como dos processos de interação entre os mesmos na dimensão espaço-temporal, que constituem elementos técnicocientíficos fundamentais para a análise do meio ambiente.

Sendo assim, a abordagem sobre o EIA/RIMA pode acontecer na maior parte das disciplinas do curso de graduação, a exemplo dos componentes da área do meio físico e biótico (geomorfologia, climatologia, recursos hídricos, sedimentologia, pedologia, biogeografia etc.), da área humana (geografia da população, geografia econômica, geografia urbana, planejamento urbano, geografia agrária etc.), da Cartografia e Geotecnologias e de disciplinas específicas da área ambiental (planejamento e gestão ambiental, avaliação de impactos ambientais, auditoria ambiental, perícia ambiental, riscos ambientais etc.).

Erroneamente existe um entendimento por uma parte dos discentes, docentes universitários e demais profissionais da geografia, de que o preparo para a "atuação como geógrafo" se restringe as disciplinas da área física e das geotecnologias, quando, na verdade, já existe uma atuação 
expressiva dos geógrafos nos estudos socioeconômicos dos EIAs. Entende-se que a formação acadêmica do Geógrafo deve privilegiar os diversos segmentos (serviço público, setor privado empregado, Organizações Não Governamentais - ONGs, consultor ambiental etc.), as grandes áreas da geografia e as disciplinas devem ser planejadas para ser executadas, considerando as demandas da realidade do mercado de trabalho do geógrafo.

Além do que foi até aqui exposto, cabe destacar a formação crítica do geógrafo, que "traz em seu bojo a capacidade crítica de pensar a sociedade e como ela age sobre a natureza" (PAES E VENTURI, 2011, p.502), o que “pressupõe-se que o aluno entre no mercado de trabalho não só bem formado teórica e tecnicamente, mas com senso crítico, exercendo seu trabalho como profissional e cidadão" (p.502). Em se tratando de atuação profissional, a ética está intrinsicamente presente, principalmente, em relação aos estudos de impacto ambiental:

O princípio ético é aquele que concerne aos princípios morais. Num estudo de impacto ambiental há que se considerar esses princípios como balizadores, como algo que de uma forma concreta estabeleça os limites de interesse e de atuação daqueles que, pensando no desenvolvimento como meta final, projetam e constroem grandes empreendimentos (VERDUM; MEDEIROS, 2002, p.142).

No campo da ética, compreende-se que uma das deficiências indicadas pelo MPF (2004) a "tendência à minimização ou subestimação dos impactos negativos e a supervalorização dos impactos positivos", constitui um exemplo típico da falta de ética profissional no momento da elaboração dos EIAs.

\section{METODOLOGIA}

Os resultados discutidos neste artigo são resultantes das atividades executadas na vigência de um projeto de pesquisa, intitulado: "A abordagem da geomorfologia nos EIAs/RIMAs no Estado da Paraíba", desenvolvido no Departamento de Geociências da Universidade Federal da Paraíba. O desenvolvimento do projeto permitiu elaborar um diagnóstico da realidade do estado da Paraíba, gerando dados e informações técnicas a respeito do uso dos conhecimentos geomorfológicos na elaboração dos EIAs/RIMAs encaminhados ao órgão ambiental do estado da Paraíba (SUDEMA Superintendência de Administração do Meio Ambiente), tendo sido gerada uma outra linha de análise, que tratou da composição e atuação dos profissionais integrantes das equipes elaboradoras dos estudos analisados, possibilitando extrair dados e informações a respeito da atuação do geógrafo.

Para a elaboração deste artigo procedeu-se ao levantamento e análise da bibliografia que contempla os diferentes assuntos abordados (EIA/RIMA, licenciamento ambiental, profissional geógrafo etc.) por meio das publicações de autores nacionais e estrangeiros (MPF, 2004; MÜLLER- 
PLANTENBERG; AB'SABER, 2006; KIRCHHOFF, 2006; PAES, 2010; SÁNCHEZ, 2013; GUTIERRES et al., 2017; PEREIRA; GUTIERRES, 2018; GUTIERRES et al., 2018), juntamente com a legislação ambiental brasileira (BRASIL, 1981; BRASIL, 1986; BRASIL, 1997; BRASIL, 2011) e a legislação profissional do geógrafo (BRASIL, 1979; BRASIL, 1980; BRASIL, 1985). O trabalho tem como base uma pesquisa aplicada e descritiva através do método documental, entendendo a pesquisa documental como aquela que "vale-se de materiais que não receberam ainda um tratamento analítico, ou que ainda podem ser reelaborados de acordo com os objetos da pesquisa" (GIL, 2010, p.45).

A coleta, leitura e análise dos EIAs/RIMAs, visando obter a composição das equipes elaboradoras e identificar a presença do geógrafo, aconteceram por meio de visitas ao Centro de Documentação (CDOC) da Superintendência de Administração do Meio Ambiente (SUDEMA) para a consulta do acervo físico dos processos de licenciamento ambiental. Após a coleta dos dados através de fichas eletrônicas e o tratamento por meio de planilhas eletrônicas, os mesmos foram organizados e apresentados em tabelas e gráficos.

\section{RESULTADOS E DISCUSSÃO}

\subsection{Panorama geral dos EIAs analisados}

A partir do que foi levantado no órgão ambiental e, posteriormente a sistematização dos dados em gabinete, procede-se a apresentação e análise do que foi obtido dos quarenta e três EIAs, sendo vinte e três estudos protocolados pela iniciativa privada e vinte estudos protocolados pelo poder público (governo estadual e prefeituras).

O primeiro aspecto analisado foi com relação ao total de profissionais das equipes elaboradoras. Foi identificado um total de 419 profissionais integrantes das equipes elaboradoras, perfazendo uma média de 10,2 profissionais para cada estudo. Já com relação às profissões desses profissionais, a figura 01 elenca os Biólogos (24\%), Geólogos (14,7\%), Geógrafos (11,2\%), Engenheiros Civis (9,1\%) e Engenheiros Florestais (5\%), seguido dos Advogados (3,3\%), Engenheiros de Minas (3,1\%), Engenheiros Agrônomos (3,1\%), Engenheiros Ambientais (2,1\%) e Economistas $(2,1 \%)$, como os profissionais que mais participaram na composição das equipes responsáveis pela elaboração dos EIAs/RIMAs analisados. 


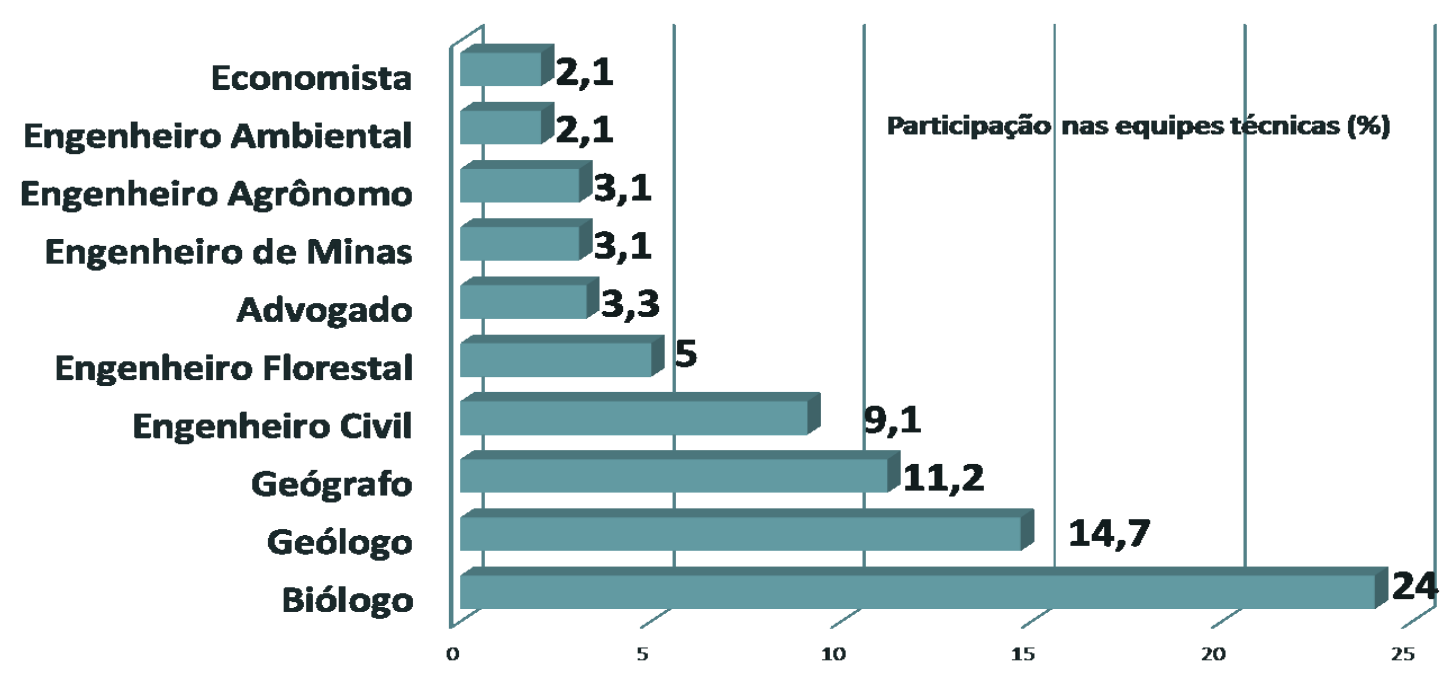

Figura 01 - Percentual de participação dos profissionais das equipes elaboradoras dos EIAs/RIMAs (2000 - 2015). Fonte: SUDEMA / Pesquisa Direta, 2018.

Org.: Autores, 2019.

Sendo assim, o Geógrafo foi o terceiro profissional mais contratado. No estado de São Paulo, Paes (2010) obteve um total de 360 profissionais, tendo o geógrafo sido o quarto profissional mais requisitado, registrando-se a presença de 30 geógrafos (8,3\% dos participantes) em 13 dos 20 estudos analisados (65\% do total), só sendo superados pelos biólogos (74), geólogos (41) e engenheiros civis (35). Apesar do recorte temporal menor e a quantidade menor de EIAs, chama atenção os dados obtidos por Paes (2010) quando comparados com a realidade da Paraíba, já que os quatro profissionais mais contratados foram verificados nas duas realidades.

Diante da expressiva participação destes profissionais nas equipes técnicas elaboradoras dos EIAs/RIMAs na Paraíba, parte-se para a análise da participação do geógrafo, observando os seguintes aspectos: número de geógrafos integrantes da equipe técnica de cada EIA; análise temporal da participação do geógrafo; as tipologias de empreendimentos que mais demandaram a presença do geógrafo; e os outros profissionais presentes nas equipes com a presença do geógrafo.

$\mathrm{Na}$ análise do número de profissionais de cada equipe, procedeu-se a organização por grupos, de acordo com a quantidade de profissionais na equipe técnica (4 a 6 profissionais; 7 a 9; 10 a 15; acima de 15), buscando entender como o geógrafo se inseriu nessa distribuição. Inicialmente, cabe apontar que do total de EIAs, treze estudos apresentaram de 4 a 6 profissionais na equipe elaboradora, representando 30,9\% do total. Portanto, quase um terço dos EIAs tiveram, no máximo, seis profissionais na equipe elaboradora. Nesse universo de 13 EIAs, em oito estudos o geógrafo integrou a equipe, o que representa $61,5 \%$ dos estudos com a presença desse profissional. Quando se consideram as equipes com 7 a 9 profissionais, este universo totaliza 26,2\% dos EIAs analisados, perfazendo um total de doze estudos. Destes, o geógrafo esteve presente em dez equipes técnicas de EIAs, o que evidencia a presença em $83,3 \%$ dos estudos. 
$\mathrm{Na}$ faixa de 10 a 15 profissionais, catorze EIAs apresentaram a quantidade de profissionais da equipe elaboradora compreendidas nesse intervalo. Desse total, em dez EIAs a equipe teve a presença do geógrafo, o que representa um índice de 71,4\%. Por fim, em quatro estudos identificouse que as equipes eram compostas por mais de quinze profissionais e em todos esses estudos o geógrafo esteve presente, o que reflete uma participação de $100 \%$ dos estudos com as maiores equipes técnicas. Portanto, verifica-se que de 42 EIAs (considerando a falta da lista de profissionais do EIA10), o geógrafo integrou 32 equipes profissionais, o que resulta numa expressiva participação de 76,2\% dos EIAs analisados.

\subsubsection{A atuação do geógrafo nas equipes elaboradoras dos EIAs}

Um outro aspecto analisado encontra-se descrito no Quadro 1, que elenca o número de geógrafos em cada equipe, relacionando a quantidade de registros e os números dos respectivos EIAs.

A maior quantidade de estudos (21 EIAs) apresentaram um geógrafo em cada equipe, totalizando $65,5 \%$ de EIAs com geógrafo na equipe. Já os EIAs com dois geógrafos em cada equipe, totalizaram oito estudos $(25 \%$ em relação ao total). Nas equipes de dois EIAs, três geógrafos compuseram cada equipe.

Quadro 1 - Quantidade de geógrafos identificados nas equipes responsáveis pela elaboração dos EIAs.

\begin{tabular}{ccc}
\hline $\begin{array}{c}\text { Número de Geógrafos na } \\
\text { equipe }\end{array}$ & $\begin{array}{c}\text { Quantidade de } \\
\text { EIAs }\end{array}$ & $\begin{array}{c}\text { Identificação dos EIAs } \\
\text { (numeração de acordo com a Quadro 2) }\end{array}$ \\
\hline 1 & 21 & $01,04,07,08,09,12,13,14,15,16,18,20,22,27,28,32,36$, \\
& $37,38,39 \mathrm{e} \mathrm{41.}$ \\
2 & 8 & $03,19,24,29,33,34,35,40$. \\
3 & 2 & 42,43 \\
4 & 0 & - \\
5 & 1 & 30 \\
\hline
\end{tabular}

Fonte: SUDEMA / Pesquisa Direta, 2018.

Org.: Autores, 2019.

Por fim, um EIA apresentou o maior número de geógrafos na mesma equipe, cinco (EIA30). Com relação aos EIAs com dois geógrafos ou mais na equipe, apesar de totalizarem 11 estudos (34,5\%) com a presença do geógrafo, estes totalizaram 27 geógrafos nas equipes, superando os 21 geógrafos dos vinte e um EIAs, que tiveram apenas um profissional da geografia.

Partindo para um aspecto temporal da análise, a figura 02 demonstra a participação do geógrafo numa perspectiva temporal, considerando o período analisado (2000-2015), buscando entender a dinâmica da participação do geógrafo ao longo desse intervalo de tempo, demonstrando 
possíveis tendências de aumento ou diminuição da oferta de oportunidades ao longo dos quinze anos. Evidencia-se que com o passar dos anos houve uma oscilação da quantidade de geógrafos que integraram as equipes elaboradoras. Contudo, cabe destacar que tal quantitativo está também diretamente relacionado ao total de EIAs por ano, que também oscilou ao longo do período analisado.

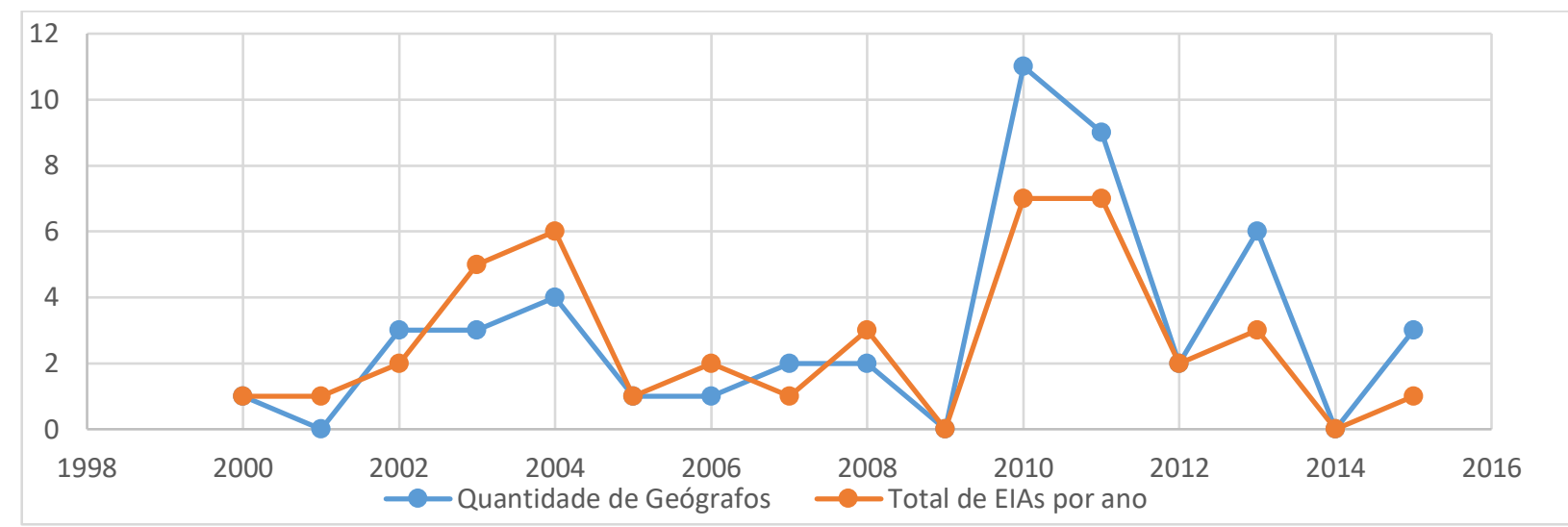

Figura 02 - Participação dos geógrafos na perspectiva temporal do período analisado (2000-2015), associando à quantidade de EIAs por ano.

Fonte: SUDEMA / Pesquisa Direta, 2018.

Org.: Autores, 2019.

É possível traçar cenários da relação entre a quantidade de geógrafos presentes nas equipes e o total de EIAs. O primeiro crescimento na quantidade de geógrafos é observado no ano de 2002, quando três geógrafos integraram as equipes dos EIAs daquele ano, sendo o primeiro ano a se observar que o número de geógrafos supera o total de EIAs/ano (algo observado também nos anos de 2007, 2010, 2011, 2013 e 2015). Em 2003, verifica-se o aumento da quantidade de EIAs, de dois para cinco, no entanto, a quantidade de geógrafos se manteve estável em relação ao ano anterior. No ano seguinte (2004), novo crescimento na quantidade de EIAs, passando para seis estudos, e um ligeiro aumento também de geógrafos, passando de três para quatro. Em 2005, constata-se uma brusca redução da quantidade de EIAs, passando de seis para um estudo. Tal comportamento foi seguido pela presença do geógrafo, tendo caído de quatro para um profissional.

O que se verifica entre os anos de 2005 e 2008 é que a quantidade de EIAs oscilou, entre um e três estudos, o mesmo acontecendo com a presença do geógrafo, que vai de um a dois profissionais. O ano de 2009, assim como o de 2014, não tiveram EIAs protocolados.

Os anos de 2010 e 2011 registraram a maior quantidade de EIAs protocolados, representando $46,5 \%$ do total de estudos ao longo dos quinze anos, bem como também são os anos com a maior presença de geógrafos nas equipes elaboradoras, tendo o pico de onze profissionais em 2010 e nove profissionais em 2011. Ou seja, 60,6\% do total de geógrafos, do período de quinze anos, compuseram as equipes dos EIAs nos anos de 2010 e 2011, o que evidencia uma concentração 
temporal no que concerne à atuação desse profissional. Já no ano de 2012 é identificada uma queda vertiginosa, tanto da quantidade de EIAs, como dos geógrafos. Enquanto isso, no ano seguinte, verifica-se um aumento para ambos os dados, principalmente no número de geógrafos, que triplica a quantidade. Por fim, o ano de 2015 tem queda, se considerarmos o ano de 2013 (já que 2014 não se protocolou nenhum EIA), mas com a quantidade de geógrafos superando o total de EIAs naquele ano.

Excluindo os anos de 2009 e 2014, os demais anos mostraram que no período considerado, seis anos (2002, 2007, 2010, 2011, 2013 e 2015), apresentaram a quantidade de geógrafos maior do que o número de EIAs, enquanto que em cinco anos (2001, 2003, 2004, 2006 e 2008) os EIAs superaram os geógrafos e em três anos houve um equilíbrio entre os dois dados (2000, 2005 e 2012). Portanto, no total de 48 geógrafos integrantes dos 32 EIAs, tem-se uma média de 1,5 geógrafo/EIA. Sendo assim, com exceção dos anos de 2000 e 2006, que apresentaram a presença de um geógrafo em cada ano, os demais anos superaram a média de 1,5 geógrafo/EIA.

Outro aspecto foi com relação as tipologias dos empreendimentos sujeitos ao licenciamento ambiental com EIA, enfatizando a presença do geógrafo nas equipes desses estudos, conforme apresentado na figura 03. De acordo com o gráfico, os geógrafos compuseram as equipes elaboradoras de EIAs de dezessete tipologias. A "indústria cimenteira" foi a mais expressiva, com quatro estudos. Em seguida, um grupo formado por cinco tipologias, tiveram três estudos, destacando-se a tipologia "mineração", tendo alguns desses EIAs associados aos da "indústria cimenteira". As tipologias "barragem" e "estocagem de combustíveis" tiveram dois EIAs cada. Por fim, nove tipologias registraram um EIA.

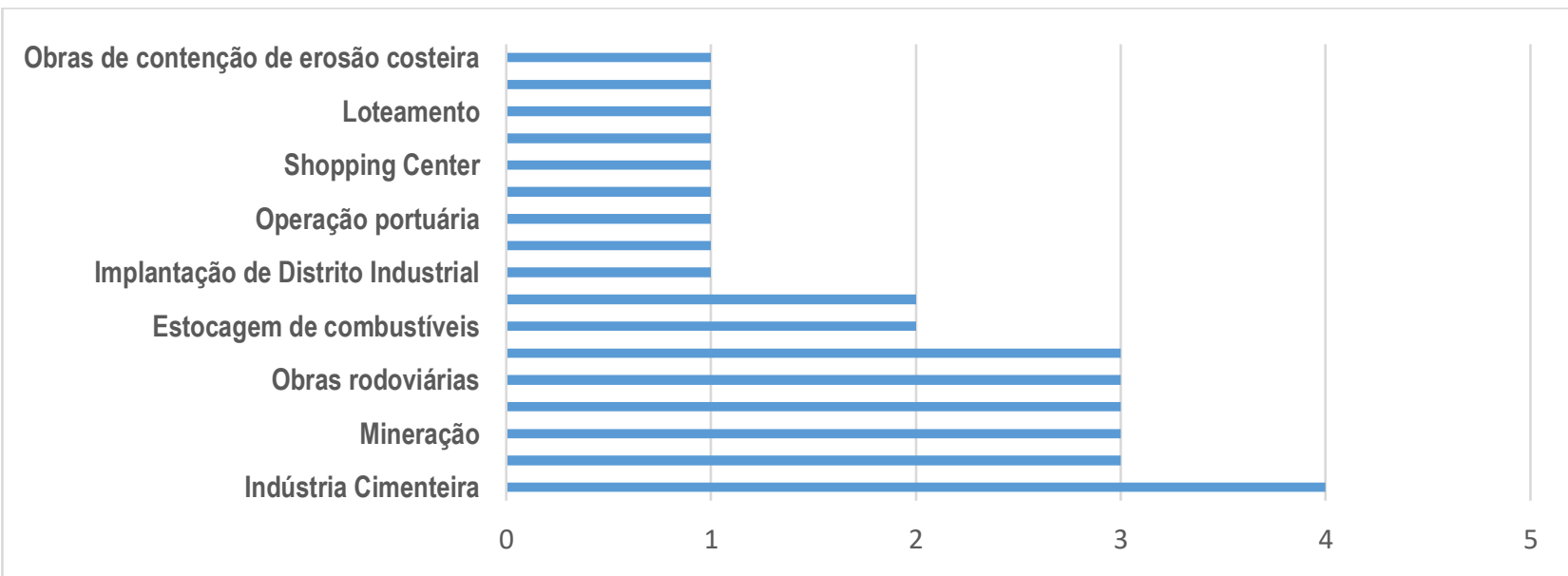

Figura 03 - Tipologias de empreendimentos que tiveram a presença do geógrafo na sua equipe técnica de elaboração do EIA/RIMA.

Fonte: SUDEMA / Pesquisa Direta, 2018.

Org.: Autores, 2019. 
O gráfico permite aprofundar o entendimento da atuação do geógrafo, buscando entender se essa maior ou menor participação pode estar condicionada aos EIAs de determinados empreendimentos/atividades.

Com relação aos outros profissionais presentes nas equipes elaboradoras que tinham a presença de, no mínimo, um geógrafo, a figura 04 expõe os vinte profissionais que foram mais identificados em tais equipes.

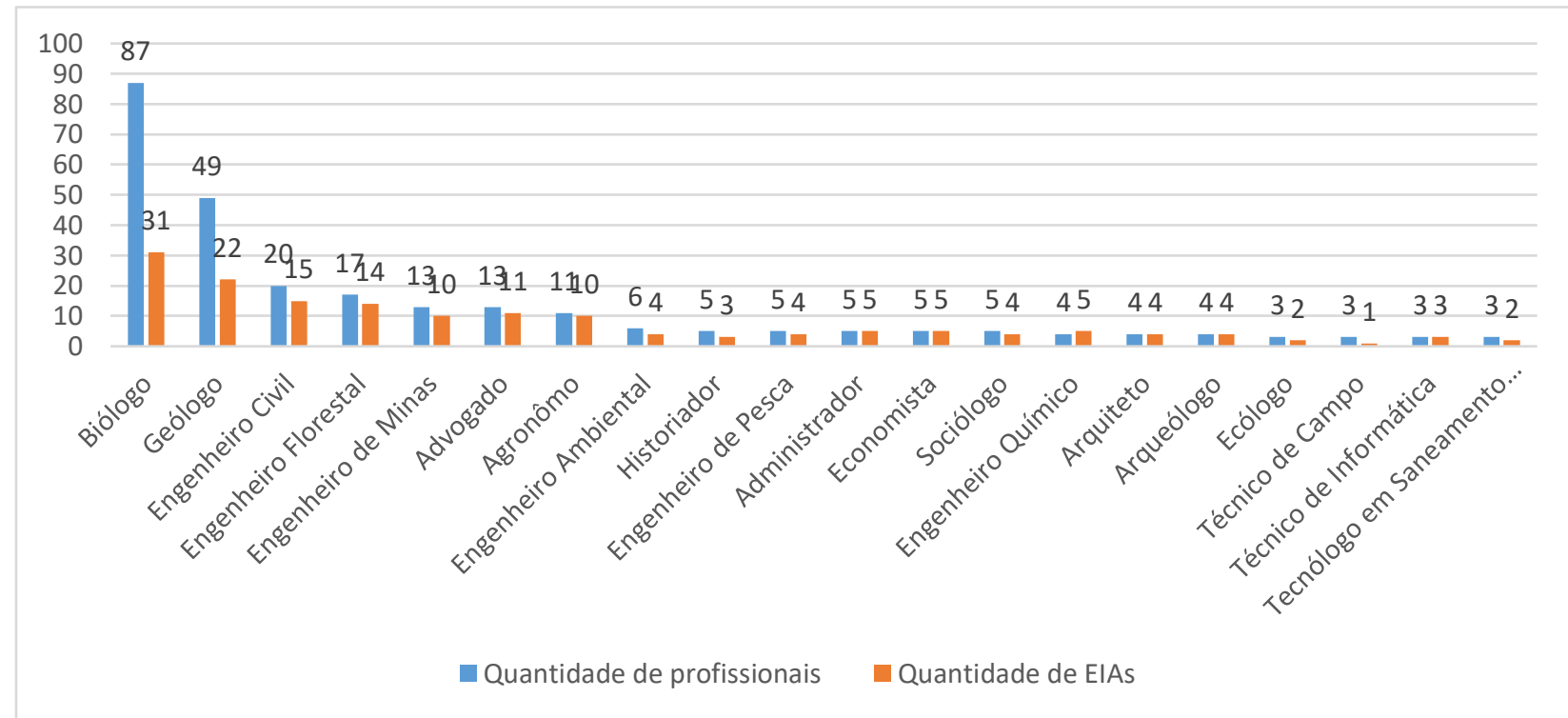

Figura 04 - Ranking da quantidade de profissionais presentes nas equipes dos EIAs com a presença do geógrafo. Fonte: SUDEMA / Pesquisa Direta, 2018.

Org.: Autores, 2019.

Os biólogos foram os mais presentes nas equipes técnicas dos EIAs que apresentaram algum geógrafo. Dos 32 EIAs com geógrafos nas equipes, os biólogos estiveram em 31 estudos (exceto o EIA 027), com um total de 87 profissionais. Em seguida aparecem os geólogos, que participaram de 22 EIAs com 49 profissionais, seguido dos Engenheiros Civis, com um total de 20 profissionais em 15 EIAs. Além desses, os Engenheiros Florestais, de Minas, Advogados e Agrônomos destacaram-se por estarem presentes em, no mínimo, 10 EIAs. Tais dados permitem traçar estratégias voltadas para a formação acadêmica e a atuação profissional do geógrafo enfocando a importância do trabalho multidisciplinar e quais profissões estão mais próximas à atuação do geógrafo no tocante à elaboração dos Estudos de Impacto Ambiental.

Outro importante ponto a ser contemplado no estudo sobre a atuação profissional do geógrafo na elaboração dos EIAs seria demonstrar, qualitativamente, em quais meios ("físico"; "biótico"; "socioeconômico", tomando a divisão proposta pela Resolução CONAMA n" 01/86), o geógrafo atuou em cada EIA. Porém, vale frisar que a maior parte dos estudos analisados não detalhava as áreas de atuação de cada profissional, o que inviabiliza uma plena análise dessa perspectiva, situação também vivenciada por Paes (2010), na realidade do estado de São Paulo. 
Contudo, mesmo sem tais informações e consultando a legislação dos outros profissionais e por meio da análise do quadro 2, é possível inferir a atuação do geógrafo em alguns dos EIAs analisados.

Quadro 2 - Lista dos EIAs analisados com a presença do geógrafo na composição da equipe profissional responsável pela elaboração.

\begin{tabular}{ccc}
\hline Código & Empreendimento & Equipe profissional* \\
\hline EIA 01 & Barragem de Camará & Agrônomo (2), Engenheiro Civil (2), Geógrafo (1), Geólogo (1), Biólogo (1), Agro-sócio \\
econômico (1)
\end{tabular}

unidade industrial de processamento de coque verde de petróleo e carvão mineral

Implantação da rede geral

EIA 07 de distribuição de gás natural

EIA $08 \quad \begin{aligned} & \text { Implantação de gasoduto } \\ & \text { (rede de distribuição }\end{aligned}$ interna)

EIA 09

Base para estocagem e distribuição de combustíveis

Operação portuária (carga e descarga de navios e 010 armazenamento de cargas em geral)

EIA

\section{Hotel Ecológico}

Implantação da Estação Ciência, Cultura e Arte Complexo Turístico Resort

Ponte (ligação rodoviária entre os municípios de Cabedelo e Lucena) Instalação de Unidade Termelétrica

Complexo Ecoturístico Reserva Garaú Aterro Sanitário de Campina Grande

Exploração de Talco e Minério de Ferro

Indústria Cimenteira

Indústria Cimenteira
Biólogo (1), Geógrafo (1), Engenheiro de Segurança/Arquiteto (1), Engenheiro Agrônomo (1), Geólogo (1)

Biólogo (2), Eng. de Minas (1), Geólogo (1), Agrônomo (1), Economista (1), Contador (1), Administrador (1), Advogado (1), Eng. Química (1), Eng. Civil (1), Geógrafo (1)

Eng. de Minas (1), Agrônomo (1), Biólogo (1), Contador (1), Administrador (1), Advogado (1), Eng. Químico (1), Eng. Civil (1), Geógrafo (1)

Geólogo (4), Biólogo (2), Eng. Civil (1), Geógrafo (1), Economista (1)

Geólogo (5), Biólogo (1), Economista (1), Eng. de Pesca (1), Geógrafo (1)

Advogado (2), Biólogo (2), Eng.de Minas (1), Geólogo (1), Eng. Agrônomo (1), Eng. Civil (1), Geógrafo (1), Administrador (1),

Tecnólogo em Geoprocessamento (2), Eng. Agrônomo (1), Eng. Civil (1), Geógrafo (1), Biólogo (1)

Biólogo (2), Geógrafo (2), Eng. Florestal (1)

Eng. de Minas / Segurança (1), Geólogo (1), Advogado (1), Eng. Químico (1), Biólogo (1), Eng. Eletricista (1), Eng. Florestal (1), Eng. Civil (1), Geógrafo (1), Técnico em Informática (1)

Biólogo (5); Letra/Cultura Popular (1); Geógrafo (1); Eng. Florestal (1)

Geólogo (3), Geógrafo (2), Biólogo (1)

Eng. Civil (1), Geólogo (1), Biólogo (1), Cadista e Design Gráfico (1), Geógrafo (1)

Eng. Civil (2), Eng. Florestal (1), Eng. de Minas (1), Sociólogo (1), Eng. Ambiental (1), Químico Industrial (1), Geólogo (1), Historiador (1), Geógrafo (1), Biólogo (1)

Biólogo (4), Eng. de Minas (2), Geógrafo (2), Eng. Florestal (1), Eng. Sanitarista e Ambiental (1), Eng. de Minas (1)

Geógrafo (5), Geólogo (4), Biólogo (2), Eng. de Pesca (2), Eng. Florestal (1), Técnico Ambiental (1) 


\begin{tabular}{|c|c|c|}
\hline $\begin{array}{l}\text { EIA } \\
021\end{array}$ & Lavra de calcário e argila & Biólogo (2), Eng. Florestal (2), Geógrafo (1), Eng. de Minas (1) \\
\hline $\begin{array}{l}\text { EIA } \\
022\end{array}$ & Indústria Cimenteira & $\begin{array}{c}\text { Geólogo (3), Geógrafo (2), Biólogo (2), Eng. Florestal (1), Técnico em Saneamento } \\
\text { Ambiental (1) }\end{array}$ \\
\hline $\begin{array}{l}\text { EIA } \\
023\end{array}$ & Shopping Center & $\begin{array}{c}\text { Geólogo (3), Geógrafo (2), Biólogo (2), Tecnólogo em Saneamento Ambiental (1), Eng. } \\
\text { Florestal (1) }\end{array}$ \\
\hline $\begin{array}{l}\text { EIA } \\
024\end{array}$ & Indústria Cimenteira & $\begin{array}{c}\text { Geólogo (3), Geógrafo (2), Biólogo (2), Eng. Florestal (1), Tecnólogo em Saneamento } \\
\text { Básico (1) }\end{array}$ \\
\hline $\begin{array}{l}\text { EIA } \\
025\end{array}$ & $\begin{array}{c}\text { Estudos da Dinâmica } \\
\text { Costeira para redução } \\
\text { /contenção do processo de } \\
\text { erosão na falésia do Cabo } \\
\text { Branco e da Praia do Seixas } \\
\text { no litoral de João Pessoa- } \\
\text { PB }\end{array}$ & Biólogo (21), Geólogo (2), Advogado (2), Geógrafo (1), Ecólogo (1), Oceanógrafo (1) \\
\hline $\begin{array}{l}\text { EIA } \\
026\end{array}$ & Termelétrica & Biólogo (2), Engenheiro Civil (2), Eng. Florestal (1), Geógrafo (1) \\
\hline $\begin{array}{l}\text { EIA } \\
027\end{array}$ & $\begin{array}{l}\text { Implantação do Distrito } \\
\text { Industrial de Caaporã }\end{array}$ & $\begin{array}{l}\text { Eng. Florestal (3), Historiador (2), Eng. Civil (1), Economista (1), Arquiteto e Urbanista (1), } \\
\text { Geógrafo (1) }\end{array}$ \\
\hline $\begin{array}{l}\text { EIA } \\
028\end{array}$ & Usinas Termelétricas & $\begin{array}{c}\text { Biólogo (3), Engenheiro Ambiental (3), Geógrafo (1), Técnico de Segurança (1), Técnico de } \\
\text { Informática (1) }\end{array}$ \\
\hline $\begin{array}{l}\text { EIA } \\
029\end{array}$ & Indústria Cimenteira & $\begin{array}{l}\text { Biólogo (4), Geógrafo (2), Eng. Minas/Advogado (1), Eng. Florestal (1); Eng. de Minas (1), } \\
\text { Eng. Ambiental (1), Arqueologia (1), Hidrogeologia (1), Paleontologia (1), Sociólogo (1) }\end{array}$ \\
\hline $\begin{array}{l}\text { EIA } \\
030\end{array}$ & Loteamento Residencial & $\begin{array}{l}\text { Eng. Civil (3), Técnico de Campo (3), Biólogo (2), Topógrafo (2), Eng. Agrônomo (1), Eng. } \\
\text { Químico (1), Veterinário (1), Geólogo (1), Geógrafo (1), Advogado (1), Arqueologia (1), } \\
\text { Paleontólogo (1), Cartógrafo (1) }\end{array}$ \\
\hline $\begin{array}{l}\text { EIA } \\
031\end{array}$ & Barragem de Cupissura & $\begin{array}{c}\text { Biólogo (7), Geógrafo (3), Eng. de Minas (1), Geólogo (1), Eng. Ambiental (1), Técnico em } \\
\text { Segurança (1), Arqueologia (1), Advogado (1), Eng. Agrônomo (1) }\end{array}$ \\
\hline $\begin{array}{l}\text { EIA } \\
032\end{array}$ & $\begin{array}{l}\text { Duplicação da Rodovia } \\
\text { BR-104 }\end{array}$ & $\begin{array}{c}\text { Biólogo (5), Geógrafo (3), Sociólogo (2), Historiador (2), Ecólogo (2), Advogado (1), } \\
\text { Geólogo (1), Tecnólogo Ambiental (1), Técnico Ambiental (1), Zootecnista (1), } \\
\text { Administrador (1), Arqueólogo (1), Publicitário (1), Agrônomo (1), }\end{array}$ \\
\hline
\end{tabular}

* Alguns termos não refletem profissões de fato, mas áreas de atuação. No entanto, optou-se em adotar fielmente aquilo que constava nos EIAs.

Fonte: SUDEMA / Pesquisa Direta, 2018.

Org.: Autores, 2019.

A análise das equipes profissionais demonstra deficiências, em alguns estudos, no tocante à compatibilidade dos profissionais em atender ao caráter multidisciplinar inerente aos três meios considerados (meio físico, meio biótico e meio socioeconômico). No entanto, restringindo a análise à atuação do geógrafo frente às demais profissões de cada estudo, as considerações a serem feitas tomam como referência as atribuições dos demais profissionais, permitindo traçar alguns cenários de atuação do(s) geógrafo(s) de cada equipe: "atuação no meio socioeconômico"; "atuação no meio físico"; "atuação nos meios físico e/ou socioeconômico"; "atuação em qualquer um dos três meios".

A “atuação no meio socioeconômico" é constatada em dezoito EIAs (01, 02, 04, 08, 011 , 012, 014, 016, 017, 019, 020, 021, 022, 023, 024, 025, 026 e 031), diante da falta de outro(s) profissional(is) na equipe que tenha(m) atribuição para atuar na área socioeconômica.

A “atuação no meio físico" é identificada no EIA 027. Já a "atuação nos meios físico e/ou socioeconômico" é identificada nos estudos (013, 015 e 028). Por fim, os demais EIAs (03, 05, 06, 07, 09, 010, 018, 024, 030 e 032) demonstram a impossibilidade em se identificar em qual ou quais 
"meios" o geógrafo ou os geógrafos da equipe atuaram, já que a equipe apresenta profissionais com atribuições que contemplam os três meios.

O fato de em 18 EIAs o geógrafo ser enquadrado como responsável pelos estudos do meio socioeconômico, ou seja, apenas uma profissão à frente de tais estudos, demonstra que existiu uma maior atenção em se contratar profissionais voltados para os meios físico e biológico com relação ao socioeconômico. Tal desvalorização do estudo socioeconômico foi destacado por Gutierres et al. (2018, p.1800), quando considera que "a negligência com os estudos do meio socioeconômico é grave, sendo um campo de extrema importância, pois tem o intuito de trabalhar os impactos benéficos e maléficos para a população, especialmente para aquelas comunidades residentes próximas ao empreendimento a ser licenciado", sendo necessário uma "mudança de mentalidade com relação à participação dos profissionais que estão aptos a atuar com as temáticas que integram o meio socioeconômico", dentre os quais se inclui o geógrafo.

Por outro lado, independente de qual foi a real atuação do geógrafo nos estudos do meio físico (e até mesmo do biológico), tal análise evidenciou a forte atuação do geógrafo na área socioeconômica, o que leva a uma mudança de mentalidade, de boa parte da comunidade geográfica, que comumente, associa a atuação do geógrafo nos EIAs a se trabalhar com os meios físico e biológico, além da cartografia e geotecnologias. Dessa forma, deve o geógrafo não praticar na sua carreira profissional aquilo que se constata em boa parte dos ambientes acadêmicos, que é a divisão entre geografia humana e física, pois "ao assumir a visão puramente humana ou física, o geógrafo impõe limites a si próprio e perde espaço em uma sociedade crescentemente competitiva" (COUTINHO, 2018, p.42). Logo, “será que a virtude do geógrafo não é ter uma vasta gama de conhecimentos num mundo de especialistas?” (SEEMANN, 2001, p.90). No entanto, defende-se que cada profissional se especialize em determinada área da geografia para fins de atuação na elaboração dos EIAs, mas buscando a transdisciplinaridade, como algo possibilitado pela sua formação acadêmica.

\subsubsection{As possibilidades de atuação do Geógrafo nos EIAs/RIMAs}

Após a discussão e análise crítica dos dados levantados, é necessário detalhar as possibilidades de atuação dos geógrafos nos EIAs/RIMAs, independente da tipologia, localização do empreendimento, órgão ambiental licenciador dentre outros aspectos. Paes e Venturi (2011, p.500/501) afirmam que a "formação diversificada, apoiada por uma ampla e variada grade curricular, [...], possibilita ao geógrafo adquirir habilidade especial para a análise integrada, que acabará sendo sua mais forte estratégia metodológica”. Carrijo (2003, p.155) comenta que:

Os EIAs-RIMAs são elaborados por equipes multidisciplinares e não interdisciplinares como seria correto, em se tratando de questões sócio-ambientais. O que é feito na verdade, é a justaposição de disciplinas acadêmicas, que relatam de maneira fragmentada seus 
conhecimentos sem uma real interação. Sendo assim, a maioria desses estudos de impacto ambiental não exprimem a realidade da dinâmica do sistema. Somente através da visão integrada é que se torna possível dimensionar os impactos que poderiam vir a ocorrer. Nesse contexto, o papel do geógrafo deve ser fundamental pois sua formação possibilita uma visão mais ampla da interação entre os aspectos sócio-econômico e físico-biótico.

Nehrer (2002) questiona se "a interdisciplinaridade tem sido uma prática na elaboração de EIA-RIMA?” e defende que a mesma se consolidará nos EIAs/RIMAs por meio de uma leitura mais holística e menos cartesiana. E finaliza afirmando que "um dia, talvez, não se discutirá mais interdisciplinaridade, pois poderemos avançar na transdisciplinaridade" (NEHRER, 2002, p.74). Pensando nesta perspectiva na realidade do geógrafo, Carrijo (2002/2003, p.155) acredita que:

Com base nesses preceitos, a Geografia deve exercer papel fundamental junto as outras ciências, na execução desses estudos em função da visão integradora que o geógrafo debruça sobre os diferentes pontos como afirma Suertegaray et al. (1988) "Apreender a realidade ambiental é tarefa atinente dos geógrafos que estariam, assim, contribuindo à compreensão da sociedade".

Tal entendimento dialoga com a figura 01 , que apresentou os profissionais que mais estiveram presentes nas equipes elaboradoras dos EIAs. Diante dos resultados discutidos, é inquestionável a inserção do geógrafo nessas equipes. Tratar das possibilidades de atuação do geógrafo na elaboração dos EIAs/RIMAs é se reportar à clássica divisão dos meios (físico, biótico e socioeconômico) e à relação com a formação dos futuros geógrafos. Para Ross (1990, p.19), “como o ambiente não é visto apenas como o meio físico e biótico, mas inclui também o sócio-econômico, isso coloca a ciência geográfica como um todo em situação de privilégio frente às demais, nas análises ambientais". A compreensão do ambiente através dos três meios citados faz com que se reporte à existência de disciplinas no currículo dos cursos de bacharelado em geografia, que dialoguem com esses três meios, a exemplo do meio físico (geologia, geomorfologia, climatologia, pedologia, recursos hídricos etc.), biótico (biogeografia, ecologia etc.) e socioeconômico (geografia urbana, agrária, econômica, da população, cultural, regional etc.), além das disciplinas instrumentais (cartografia digital, sensoriamento remoto, Sistema de Informação Geográfica - SIG, topografia, etc.) e aquelas de cunho ambiental (planejamento ambiental, gestão ambiental, avaliação de impactos ambientais, auditoria ambiental, perícia ambiental, licenciamento ambiental etc.), que dão os meios para uma formação técnico-científica voltada à questão ambiental. Obviamente que se defende que cada geógrafo busque atuar na área que tenha adquirido maior especialização e domínio teórico e prático, permitindo que a sua participação na equipe elaboradora favoreçam a uma elaboração com profundidade, rigor metodológico e resultados consistentes e práticos que, de fato, contribuam para uma previsão e avaliação dos impactos significativos. Paes e Venturi (2011) elencam exemplos dos estudos passíveis de serem elaborados pelo geógrafo: uso e ocupação do solo; socioeconômico; sistema viário; resíduos sólidos; climatológico; qualidade do ar; 
geomorfológico; pedológico; hidrológico; vegetação; cartografia/Geoprocessamento/SIG aplicados aos diversos estudos.

\subsection{Meio Físico}

\subsubsection{Estudo Climatológico}

Este é um aspecto presente em todos os EIAs e, em alguns, com maior destaque, devido à grande influência que pode exercer no desenvolvimento das atividades de um determinado empreendimento. Em se tratando de uma área urbana, por exemplo, pode gerar alterações no clima urbano ou na análise de variáveis, a exemplo da direção e da intensidade de ventos em algumas indústrias. Como também a investigação de áreas com consideráveis índices pluviométricos, desencadeadores de enchentes, erosão, movimentos de massa etc. A habilidade em elaborar mapas, gráficos, tabelas e relatórios sinópticos, destacando variações sazonais e eventos extremos, são fundamentais para este tipo de estudo.

A qualidade do ar é um dos itens presentes no estudo climatológico de um EIA, a exemplo dos estudos de dispersão atmosférica, essenciais para alguns empreendimentos, como as indústrias cimenteiras. No entanto, Paes e Venturi (2011, p.509) afirmam que "os geógrafos que conhecemos não têm elaborado esses estudos, somente aqueles de qualidade do ar, menos densos tecnicamente para empreendimentos de menor impacto neste aspecto". Aspectos como o mapeamento dos pontos de medição, a avaliação das fontes fixas e móveis emissoras de poluentes na área de influência, a concentração dos poluentes atmosféricos, a avaliação das concentrações dos poluentes e particulados produzidos e a avaliação da dispersão dos poluentes são exemplos do que pode ser trabalhado nesse tipo de estudo.

Sendo assim, é fundamental a existência de mais de uma disciplina de Climatologia, além de uma específica ou que contemple os aspectos relacionados à poluição atmosférica. Disciplinas como geomorfologia, pedologia, hidrografia e biogeografia estão relacionadas e podem contribuir. Assim como a Geografia Urbana, em especial no tocante ao uso e ocupação do solo, ao clima urbano e à ocorrência de desastres. Ou a geografia agrária, no que tange à dinâmica climática na região e os possíveis efeitos adversos para o desenvolvimento de atividades primárias, o que também permite um diálogo com a área da Geografia Econômica.

\subsubsection{Estudo Geomorfológico}


Consiste no mapeamento geomorfológico, especialmente da Área Diretamente Afetada (ADA) e do seu entorno, apresentando os diferentes compartimentos, feições do relevo e processos associados à dinâmica geomorfológica. Algumas áreas da geomorfologia deverão ser contempladas de acordo com a localização do empreendimento/atividade e o alcance dos seus impactos, a exemplo da Geomorfologia Costeira, Geomorfologia Fluvial, Geomorfologia Cárstica, Geodiversidade etc. Outra contribuição está associada à relação entre Geomorfologia e a Legislação Ambiental e Urbanística, especialmente nos aspectos referentes às restrições de uso e ocupação do solo e aos riscos geomorfológicos. Além disso, a compartimentação geomorfológica também subsidiará a análise da dinâmica da área quanto à propensão aos processos da dinâmica externa (erosão, movimentos de massa, assoreamento, inundação, colapso, subsidência etc.), que podem ocasionar problemas durante a vida útil do empreendimento. Dando suporte a tal estudo, o mapeamento geomorfológico se faz necessário e é um campo profícuo para o geógrafo.

\section{$\underline{3.2 .3 \text { Estudo Pedológico }}$}

Busca-se a caracterização dos tipos de solo presentes na área de interesse, devendo expor "as potencialidades e fragilidades do solo em que se vai empreender uma nova implantação, de forma descritiva e também por meio do mapeamento do local e de suas áreas de influência" (PAES E VENTURI, 2011, p.511). Obviamente, caso tal abordagem seja voltada aos aspectos edafológicos, se estará diante de uma atribuição do engenheiro agrônomo. No entanto, o geógrafo pode atuar junto à caracterização desse solo no tocante à fragilidade e a propensão aos processos erosivos e movimentos de massa. Infelizmente, acontece de se encontrar cursos em que a disciplina de "Pedologia" não se encontra no rol das obrigatórias, já que em sendo optativa, nem sempre a oferta da mesma acontece em todos os períodos. Defende-se a existência de duas disciplinas de Pedologia, em que se permita a inserção de práticas de campo e laboratório no que tange esse ramo científico, sendo essencial para a compreensão holística de áreas como geomorfologia, biogeografia, geologia e hidrologia.

\subsubsection{Estudo Hidrológico}

A bacia hidrográfica é utilizada, na maioria das vezes, como parâmetro de previsão e análise dos impactos ambientais de diversos empreendimentos/atividades. A bacia tem sido abordada, em alguns EIAs, como área de influência direta ou área de influência indireta. Conhecer a dinâmica e saber fazer a leitura dos dados de estações pluviométricas e fluviométricas são práticas fundamentais. Como exemplo de deficiência em EIAs na questão hidrológica, o MPF (2004) aponta a "ausência de dados que abarquem um ano hidrológico, no mínimo" como representativo num 
conjunto de EIAs analisados. É uma área que guarda estreita relação com a climatologia, geomorfologia, geologia, vegetação, atividades econômicas e o uso e a ocupação do solo.

\subsection{Meio Biótico}

\subsubsection{Estudo da Vegetação}

Segundo Paes e Venturi (2011), esse estudo desperta grande interesse por parte dos órgãos ambientais por se constituírem em indicadores da qualidade ambiental, a exemplo da valorização da paisagem local, por servir de abrigo para a fauna, proteção dos solos e ganho de infiltração da água, capacidade de fixação de carbono etc. Para os autores:

não é tarefa do geógrafo fazer minuciosos levantamentos de flora, pois isso não é contemplado em seu currículo de formação. O geógrafo deve identificar, no entanto, aspectos gerais da cobertura vegetal: se se trata de mata nativa, reflorestamento (exótica), sua importância para a região de estudo (conexão com outros fragmentos) e, mais especificamente, se aquela cobertura está em regeneração ou não, o que pode ser evidenciado por alguns indicadores (PAES E VENTURI, 2011, p.512).

Neste estudo está também contemplada a abordagem sobre áreas protegidas, principalmente a Reserva Legal (caso se aplique à realidade do empreendimento), Áreas de Preservação Permanente (APPs) e as Unidades de Conservação, o que exige um bom nível de conhecimento da legislação ambiental. A descrição, caracterização e mapeamento dos diferentes tipos de ecossistemas presentes nas áreas de influência do empreendimento possibilitam meios para a elaboração de mapas temáticos, o que possibilitará outros mapeamentos, a exemplo de poder se classificar as áreas pelo nível de sensibilidade ambiental decorrente da instalação e operação do empreendimento.

Logo, conhecimentos das áreas de Biogeografia, Geomorfologia, Pedologia e Cartografia são essenciais. Apesar de alguns cursos de geografia no Brasil não ofertarem em seus currículos, compreende-se a necessidade da oferta da disciplina de Ecologia, que gera um enriquecimento com as outras citadas, bem como aproxima o geógrafo do diálogo multidisciplinar junto a outros profissionais ligados à vegetação, a exemplo dos biólogos, ecólogos e engenheiros florestais.

\subsection{Meio Socioeconômico}

\subsubsection{Estudo Socioeconômico}

Utiliza fontes de dados demográficos secundários (Instituto Brasileiro de Geografia e Estatística - IBGE, órgãos estaduais/municipais de dados socioeconômicos) e a obtenção de dados primários por meio da pesquisa de campo junto aos órgãos públicos locais, empresas, entidades 
civis e população local, devendo, no caso dos moradores residentes nas áreas de influência do futuro empreendimento, serem aplicados questionários ou realizadas entrevistas.

Paes e Venturi (2011) destacam a possibilidade da inserção do conceito de lugar e de espaço total (Ab'Saber) nos estudos socioeconômicos dos EIAs. No tocante à infraestrutura, devese contemplar a saúde, educação, sistema viário e estrutura urbana. Além disso, deve-se analisar a dinâmica territorial - uso e ocupação do solo, conflitos de uso, atividades produtivas, patrimônio histórico, cultural e arqueológico.

O sistema viário está presente em muitos EIAs, tendo como base o Plano Diretor Municipal e demais normas da legislação urbanística, pois a nova atividade ou empreendimento pode gerar impactos no tocante à movimentação de pessoas, mercadorias e prestação de serviços. Sendo assim, compreender a infraestrutura existente e a necessidade de ampliação ou criação de novas vias decorrentes do novo empreendimento/atividade é uma das preocupações a serem estabelecidas no EIA. As "alternativas técnicas e locacionais" exigidas pela legislação na estrutura do EIA, dialoga diretamente com este tipo de estudo. Logo, áreas como a Geografia Urbana, Planejamento Urbano, Geografia Regional, Geografia da População, Geografia Econômica, Cartografia Temática, Sensoriamento Remoto e SIG são essenciais no fornecimento de conhecimentos e procedimentos úteis para a elaboração do estudo do meio socioeconômico, conforme previsto na Resolução CONAMA n ${ }^{\circ}$ 01/86.

$\mathrm{Na}$ Geografia Urbana, a familiaridade do geógrafo com instrumentos previstos no Estatuto das Cidades (Lei Federal no 10.257/2001) e a prática baseada em Planos Diretores, são exemplos da possibilidade de atuação deste profissional nessa área. Neste campo do conhecimento, o MPF (2004) aponta a falta da "não adoção de uma abordagem urbanística integrada em diagnósticos de áreas e populações urbanas afetadas" nos EIAs, o que constitui um campo de atuação que pode ser bem tratado pelo geógrafo. Ainda no estudo do meio antrópico, outras deficiências apontadas pelo MPF (2004), a exemplo da análise superficial de questões, como: movimentos migratórios; situação fundiária e especulação imobiliária; expansão da fronteira agrícola; exploração predatória de recursos naturais; economia do turismo, constituindo assuntos de interesse na atuação profissional do geógrafo.

\subsubsection{Estudo sobre a População}

Devem ser apresentados a quantidade, a distribuição e o mapeamento da população, enfatizando a densidade populacional, mapeamento das aglomerações urbanas, zoneamentos existentes, organização social, nível de instrução, emprego e renda, condições de habitação, populações tradicionais, população residente e população flutuante. 
No estudo da população e das comunidades, o conceito com viés geográfico de lugar, se destaca na compreensão dos efeitos que um empreendimento pode proporcionar a essas pessoas e, no caso de empreendimentos/atividades que impliquem na retirada das pessoas de uma determinada área, qual a percepção das mesmas para esse tipo de situação.

As preocupações com a determinação da amostragem das pessoas a serem entrevistadas e a distribuição espacial para aplicação desses questionários, são alguns dos cuidados que o profissional deve ter. Busca-se verificar quais os problemas das comunidades mais relevantes, os anseios e as perspectivas dos moradores com relação ao empreendimento, de modo a também subsidiar o planejamento das ações a serem executadas pelo empreendedor.

\subsubsection{Estudo de Uso e Ocupação do Solo}

Este estudo permite descrever as características atuais do tipo de ocupação da área e do seu entorno (categorias de análise mais usadas: área residencial; área comercial e de serviços; área mista; área verde; área industrial etc.). Caso seja pertinente ou solicitado no Termo de Referência, é possível demonstrar um uso e uma ocupação da área ao longo de certo tempo. Além disso, é um dos estudos que contribui para a definição dos limites das áreas geográficas de influência do empreendimento (Área Diretamente Afetada - ADA; Área de Influência Direta - AID e a Área de Influência Indireta - AII), considerando a bacia hidrográfica na qual se localiza. Para a execução deste tipo de estudo, o levantamento de campo e o uso/elaboração de materiais cartográficos são essenciais. A Cartografia Temática, o Sensoriamento Remoto e o SIG são de grande relevância para este estudo, pois permitirão a geração do mapa de uso e ocupação do solo.

\subsubsection{Cartografia e Geotecnologias}

Não foi utilizado o termo "estudo" antecedendo as áreas citadas, pois as mesmas se constituem em ferramentas para a análise dos diversos estudos que compõem um EIA, em qualquer um dos três meios (físico, biótico e socioeconômico). Dada a grande familiaridade da Geografia com essas áreas, as mesmas serão enfatizadas como mais uma possibilidade de atuação do geógrafo. O MPF (2004) destaca a "ausência de mapas temáticos" e a "utilização de mapas em escala inadequada, desatualizados e/ou com ausência de informações”, como deficiências comuns encontradas nos EIAs analisados pelo órgão. João (2002) demonstra a importância do uso correto da escala nos mapas de estudos ambientais, como forma de alertar, por meio da comparação de mapas com escalas diferentes e como isso resulta numa diferença considerável do detalhamento das informações a serem passadas. Para Paes e Venturi (2011, p.513), “essas são áreas de atuação de muita evidência para os geógrafos que trabalham nos estudos de impacto ambiental. Trata-se de um 
setor no qual a busca de profissionais formados em Geografia ainda é grande, embora pessoas com outras formações também disputem este mercado".

Por fim, a coordenação do EIA, que pode ficar a cargo de qualquer outra profissão, tem no geógrafo um potencial profissional apto para tal encargo, já que o EIA se constitui no conjunto de estudos que devem ser elaborados pelos mais diversos profissionais. O coordenador deve se encarregar de indicar as tarefas de cada membro e acompanhar a execução das suas atividades com base no Termo de Referência e na legislação aplicável, além de articular os diversos estudos elaborados, buscando a unidade do EIA. Em especial, garantir que se faça um bom diagnóstico ambiental, para que tais conhecimentos sejam bem utilizados no momento da avaliação dos impactos, na definição e detalhamento das medidas mitigadoras e dos programas de monitoramento. Sobre isso, o MPF (2004, p.32) afirma que "é exemplar a subutilização de dados do diagnóstico do meio físico, em que extensas informações sobre geomorfologia, pedologia e clima são pouco utilizadas nas etapas posteriores do EIA". Dada as deficiências na elaboração do diagnóstico, a "não identificação de determinados impactos" e a "subutilização ou desconsideração de dados dos diagnósticos" foram duas deficiências comumente identificadas nos EIAs analisados pelo MPF (2004).

Além disso, normalmente, o coordenador do EIA é o profissional responsável pela comunicação com o empreendedor, com o órgão ambiental licenciador (e outros órgãos públicos), além de ficar à frente da apresentação na Audiência Pública (caso esta seja realizada - Resolução CONAMA n ${ }^{\circ}$ 09/87). Sendo assim, uma função que exige conhecimentos dos procedimentos e ritos ligados ao licenciamento ambiental, exigindo vasto conhecimento da legislação, além de certa experiência profissional e boas características pessoais a fim de dirimir conflitos. Além disso, o coordenador necessita ter um bom poder de análise minuciosa para verificar se os dados e as informações foram incluídos nos estudos, conforme exige a legislação ambiental e o termo de referência do EIA disponibilizado pelo órgão ambiental licenciador. Segundo Paes e Venturi (2011, p. 501):

\footnotetext{
Esse conhecimento multidisciplinar associado à análise integrada delega, com propriedade ao geógrafo, funções como a de coordenador de estudos de impacto ambiental, por ser essa uma tarefa que exige conhecimento bastante amplo e articulado; que envolve as dimensões física (abiótica), biótica e antrópica (social, num sentido mais amplo); que deve apreender os impactos de forma integrada e não fragmentada, como é comum em muitos estudos protocolados nas instâncias legais.
}

Portanto, para o geógrafo que almeja assumir tal incumbência, não basta a simples formação do curso de graduação, mas a experiência nesse tipo de atividade profíssional, o amplo conhecimento da legislação ambiental e dos métodos de avaliação de impacto ambiental. 
Atentar para a equipe profissional elaboradora do EIA é de fundamental importância para um maior nível de sucesso do estudo a ser elaborado, já que a previsão de impactos ambientais é uma atividade de natureza indutiva, necessitando de conhecimentos do empreendimento, bem como do ambiente onde o mesmo será implantado e das suas áreas de influência. Sendo assim, o ato de prever sem ter algo construído e operando, exige da equipe elaboradora conhecimentos, experiência e capacidade de entender o futuro uso da área.

Sendo assim, concebe-se o EIA como instrumento de gestão ambiental, tanto de empreendimentos públicos como privados, sendo tal área de atuação também inerente ao geógrafo, como também entende Pacheco (2018), que apresenta algumas contribuições potenciais dos geógrafos para o processo de gestão ambiental empresarial no contexto brasileiro. Por fim, o MPF (2004) elenca uma série de ações para a melhoria da qualidade dos EIAs, destacando-se uma diretamente relacionada à atuação profissional: "maior integração e diversidade disciplinar das equipes que executam os diferentes estudos que compõem um mesmo EIA, promovendo a interdisciplinaridade". Sem dúvida, o geógrafo tem muito a contribuir com essa recomendação.

\section{CONSIDERAÇÕES FINAIS}

Para que cada vez mais os geógrafos se façam presentes nas equipes elaboradoras de EIAs, os cursos de bacharelado em Geografia necessitam incorporar disciplinas voltadas para esses estudos, que em algumas universidades já são ofertadas ("planejamento ambiental”; "planejamento e gestão ambiental"; "estudos de impacto ambiental"). Contudo, pode-se considerar que, além das disciplinas específicas, salienta-se a importância em incluir, nas diversas disciplinas do curso, que os assuntos passíveis de serem aplicados nos EIAs, sejam ensinados de maneira aplicada à realidade da atuação profissional. Dessa forma, é urgente a busca por uma maior capacitação para a elaboração dos EIAs/RIMAs. Assim, segundo as palavras de Paes e Venturi (2011, p.499), “a elaboração de Estudos de Impacto Ambiental (EIA) tem sido e continuará sendo um campo fértil de atuação profissional para o geógrafo". Sendo assim, é de grande necessidade que os geógrafos conheçam as particularidades dessa atividade e as competências e fragilidades concernentes à profissão (PAES; VENTURI, 2011).

Espera-se que os dados apresentados demonstrem a importância dessa área de atuação para o geógrafo, evidenciando suas potencialidades e fragilidades. Logo, a metodologia aplicada permite que outros estudos possam levantar e analisar dados de mesma natureza em outros estados brasileiros. E que desperte maior reflexão do mercado de trabalho do geógrafo junto aos cursos de bacharelado em Geografia, profissionais, estudantes, das Associações Profissionais dos Geógrafos (APROGEOs), Associação dos Geógrafos Brasileiros (AGB) e demais entidades que venham a 
discutir a profissão. Também espera-se que o presente artigo contribua na formação dos futuros geógrafos, considerando que a formação do profissional não acontece, apenas, por meio das disciplinas obrigatórias, como também cursando disciplinas optativas, realizando estágios, participando de projetos (iniciação científica, extensão etc.), atuando junto à Empresa Jr. do curso, executando trabalhos de campo e de laboratório.

Por fim, vale frisar que o maior rigor na análise da qualidade dos EIAs e um maior investimento em multidisciplinaridade das equipes de servidores dos órgãos ambientais, por meio da contratação via concurso público, resultarão em condições favoráveis para uma maior abertura do mercado de trabalho para o geógrafo e demais profissões.

\section{REFERÊNCIAS}

AB'SABER, A.N. O que é ser geógrafo: memórias profissionais de Aziz Ab'Saber. 1.ed. Rio de Janeiro: Record, 2007. 207p.

ANDRADE, M. C. de. Perspectivas do papel do Geógrafo, como profissional, no Brasil. Boletim de Geografia Teorética, Rio Claro, v. 16/17, n. 31-34, p. 409-422, 1986/1987.

ASSOCIAÇÃO PROFISSIONAL DOS GEÓGRAFOS DO ESTADO DO CEARÁ - APROGEOCE. Pesquisa performativa sobre o perfil do profissional geógrafo no Ceará. 1. ed. Fortaleza: Premius, 2015, 184p.

BITAR, O. Y.; ORTEGA, R. D.; GALLARDO, A. L. C. F. Avaliação de impactos. In: OLIVEIRA, A. M. dos S.; MONTICELI, J. J. Geologia de Engenharia e Ambiental - volume 3. São Paulo: ABGE, 2018. cap. 34, p. 207-225.

BRASIL. Lei $n^{0}$ 6.938, de 31 de agosto de 1981. Dispõe sobre a Política Nacional do Meio Ambiente, seus fins e mecanismos de formulação e aplicação, e dá outras providências. Disponível em: < http://www.planalto.gov.br/ccivil_03/Leis/L6938.htm> Acesso em: 02 fev. 2019.

BRASIL. Lei Complementar $n^{0}$ 140, de 08 de dezembro de 2011. Fixa normas para a cooperação entre a União, os Estados, o Distrito Federal e os Municípios nas ações administrativas decorrentes do exercício da competência comum relativas à proteção das paisagens naturais notáveis, à proteção do meio ambiente, ao combate à poluição em qualquer de suas formas e à preservação das florestas, da fauna e da flora. Disponível em: < http://www.planalto.gov.br/ccivil_03/leis/lcp/lcp140.htm> Acesso em: 05 fev. 2019.

BRASIL. Lei no 6.664, de 26 de junho de 1979. Disciplina a profissão de Geógrafo, e dá outras providências. Disponível em: < http://www.planalto.gov.br/ccivil_03/leis/1970-1979/L6664.htm > Acesso em: 14 jan. 2019.

BRASIL. Decreto $\mathbf{n}^{\mathbf{0}} \mathbf{8 5 . 1 3 8}$, de 15 de setembro de 1980. Regulamenta a Lei ${ }^{\mathbf{0}} 6.664$, de 26 de junho de 1979, que disciplina a profissão de Geógrafo, e dá outras providências. Disponível em: < http://www.planalto.gov.br/ccivil_03/decreto/1980-1989/1980-1984/D85138.htm> Acesso em: 14 jan. 2019. 
BRASIL. Lei $n^{0}$ 7.399, de 04 de novembro de 1985. Altera a redação da Lei no 6.664, de 26 de junho de 1979, que disciplina a profissão de Geógrafo. Disponível em: < $\underline{\text { http://www.planalto. }}$ gov.br/ccivil 03/leis/1980-1988/L7399.htm> Acesso em: 14 jan. 2019.

BRASIL. CONAMA. CONSELHO NACIONAL DO MEIO AMBIENTE. Resolução no 001, de 23 de janeiro de 1986. Disponível em: < http://www.mma.gov.br/ port/conama/res/res86/ res0186.html >. Acesso em: 14 fev. 2019.

BRASIL. CONAMA. CONSELHO NACIONAL DO MEIO AMBIENTE. Resolução no 237, de 19 de dezembro de 1997. Disponível em: <http://www.mma.gov.br/port/ conama/res/res97/res23797.html>. Acesso em: 14 fev. 2019.

BRASIL. Ministério da Educação. Conselho Nacional de Educação. Parecer CNE/CES 492/2001. Trata das Diretrizes Curriculares Nacionais dos cursos de Filosofia, História, Geografia, Serviço Social, Ciências Sociais, Letras, Biblioteconomia, Arquivologia e Museologia. Diário Oficial da União, Brasília, 9 jul 2001.

BRASIL. Ministério do Trabalho e Emprego. Classificação Brasileira de Ocupações - CBO. Brasília, TEM/SPPE, 2013.

CARRIJO, B. R. Contribuição à análise crítica de relatórios de impacto ambiental com enfoque em usinas hidrelétricas. Sociedade \& Natureza, Uberlândia, v. 14 e 15, n. 26 a 29, p. 151-160, 2002/2003.

CHRISTOFOLETTI, A. Modelagem de sistemas ambientais. 1. ed. São Paulo: Edgard Blücher, 1999. 256p.

COUTINHO, L. M. Por uma Engenharia Geográfica: da técnica na geografia a uma geografia técnica. Vértices, Campos dos Goytacazes, v. 20, n. 1, p. 38-53, 2018.

CREA-CE. Manual de Fiscalização: normas e procedimentos para atuação na área de Geografia no CREA-CE. 1. ed. Fortaleza: CREA-CE, 2002. 29p.

GIL, A. C. Como elaborar projetos de Pesquisa. 5. ed. São Paulo: Atlas, 2010. 200p.

GLASSON, J.; SALVADOR, N. N. B. EIA in Brazil: a procedures-practice gap. A comparative study with reference to the European Union, and especially the UK. Environmental Impact Assessment Review, v. 20, p. 191-225, 2000.

GUTIERRES, H. E. P.; SANTOS, C. J. S.; RODRIGUES, J. O. N.; PEREIRA, V. D. A abordagem geomorfológica nos Estudos de Impacto Ambiental: a realidade do estado da Paraíba entre os anos de 2005 e 2014. In: SILVA, A. B.; GuTIERRES, H. E. P.; GAlVÃO, J. C. (Org.). Paraíba: pluralidade e representações geográficas 2. Campina Grande: EDUFCG, Campina Grande, 2017. cap. 3 , p. 53-72.

GUTIERRES, H. E. P.; SANTOS, C. J. S.; RODRIGUES, J. O. N.; PEREIRA, V. D. As equipes profissionais elaboradoras dos Estudos e Relatórios de Impacto Ambiental (EIAs/RIMAs): uma contribuição para o aprimoramento do licenciamento ambiental no Brasil. Revista Brasileira de Geografia Física, Recife, v. 11, n. 5, 2018, p.1786-1802, 2018.

JOÃO, E. How scale affects environmental impact assessment. Environmental Impact Assessment Review, Scotland, v. 22, n. 4, p. 289-310, 2002. 
KIRCHHOFF, D. Capacity Building for EIA in Brazil: Preliminary Considerations and Problems to Be Overcome. Journal of Environmental Assessment Policy and Management, v. 8, n. 1, p. 1$18,2006$.

MARANGON, A. M. M. C. O Geógrafo no Brasil: alguns problemas para o seu desempenho profissional. Boletim de Geografia Teorética, Rio Claro, v. 16/17, n. 31-34, p. 137-142, 1986/1987.

MORGAN, R. K.; HART, A.; FREEMAN, C.; COUTTS, B.; COLWILl, D.; HugheS, A. Practitioners, professional cultures, and perceptions of impact assessment. Environmental Impact Assessment Review, v. 32, n. 1, p. 11-24, 2012.

MPF - Ministério Público Federal. Deficiências em estudos de impacto ambiental: síntese de uma experiência. Brasília: Escola Superior do Ministério Público, 2004. 48p.

MÜller-PlantenberG, C.; AB'SABER, A. (Orgs.). Previsão de Impactos: O Estudo de Impacto Ambiental no Leste, Oeste e Sul. Experiências no Brasil, Rússia e Alemanha. 2. ed. São Paulo: Edusp, 2006. 576p.

NEHRER, R. A. Interdisciplinaridade tem sido uma prática na elaboração de EIA/RIMA? In: VERDUM, R.; MEDEIROS, R. M. (Org.). RIMA - Relatório de Impacto Ambiental. Porto Alegre: Ed. UFRGS, 2002. p. 72-74.

PACHECO, R. C. Geografia e gestão ambiental empresarial: uma análise crítica. Caderno de Geografia, Belo Horizonte, v. 28, n. 52, p.42-53, 2018.

PAES, H. G. Contribuições da Geografia ao licenciamento e ao Estudo de Impacto Ambiental. 2010. 148 f. Dissertação (Mestrado em Geografia Física) - Faculdade de Filosofia, Letras e Ciências Humanas, Universidade de São Paulo, São Paulo, 2010.

PAES, H. G.; VENTURI, L.A.B. Profissão: geógrafo. In: VENTURI, L. A. B. (Org.). Geografia: práticas de campo, laboratório e sala de aula. São Paulo: editora Sarandi, 2011. cap. 24 , p. $495-518$.

PEREIRA, V. D.; GUTIERRES, H. E. P. Análise da distribuição territorial dos empreendimentos com EIAs/RIMAs no Estado da Paraíba nos anos de 2003 a 2014. Revista de Geografia (UFPE), Recife, v. 35, n. 3, p. 177-196, 2018.

ROSA, R. O geógrafo: atividades e mercado de trabalho. Educação e Filosofia, Uberlândia, v. 4, n. 2, p. 79-84, 1988.

ROSS, J. L. S. Geomorfologia, ambiente e planejamento. 1. ed. São Paulo: Contexto, 1990. 88p.

SAMPAIO, T. V. M.; PELEGRINA, M. A.; SOPCHAKI, C. H. Exercício profissional do geógrafo no estado do Paraná: convergências e divergências entre a lei do geógrafo, as diretrizes curriculares nacionais, as matrizes curriculares e a prática profissional. Raega - O Espaço Geográfico em Análise, Curitiba, v. 42, p. 269-287, 2017.

SÁNCHEZ, L. E. Avaliação de impacto ambiental: conceitos e métodos. 2. ed. São Paulo: Oficina de Textos, 2013. 584p. 
SANCHES, C. C.; VILlalobOS, J. U. G. Análise do EPIA (Estudo Prévio de Impacto Ambiental) referente ao empreendimento Condomínio Green Diamond Residence, com ênfase no recurso ambiental solo. Revista Brasileira de Geografia Física, Recife, v. 11, n. 04, p. 1384-1400, 2018.

SEEMANN, J. Geógrafos e Geografias - contribuições para a discussão sobre a (não) importância da geografia. Revista da Casa da Geografia de Sobral, Sobral, v. 2, n. 1, p. 87-95, 2000.

SIGNORI, L. C.; VERDUM, R. O mercado de trabalho para os geógrafos no serviço público federal. Boletim Gaúcho de Geografia, Porto Alegre, v. 35, n. 1, p. 133-148, 2009.

SILVA, A. C. O que é o Geógrafo profissional? Revista do Departamento de Geografia, São Paulo, v. 2, p. 81-92, 1983.

SILVA, J. A. Direito Ambiental Constitucional. 4. ed. São Paulo: Malheiros, 2002. 349p.

SUERTEGARAY, D. M. A.; SCHÄFFER, N. O. Análise Ambiental: a atuação do geógrafo para e na sociedade - Porto Alegre: a metrópole e seu delta. Revista Terra Livre, São Paulo, n. 3, p.89$104,1988$.

VELOSO, M. E. de L. O geógrafo e a futura série ISO 14.000. In: PEDROSO, N. G. (org.). Geógrafos: legislação, formação e mercado de trabalho. São Paulo: Associação dos Geógrafos Brasileiros / Conselho Federal de Engenharia, Arquitetura e Agronomia, 1996. p. 37-50.

VERDUM, R.; MEDEIROS, R.M.V. (Orgs.). RIMA - Relatório de Impacto Ambiental: legislação, elaboração e resultados. 4. ed. Porto Alegre: ed. UFRGS, 2002. 210p.

VERDUM, R. Os geógrafos frente às dinâmicas socioambientais no Brasil. Revista do Departamento de Geografia, São Paulo, v. 16, p. 91-94, 2005. 